\title{
Sixteenth-century tomatoes in Europe: who saw them, how they looked like, and where they came from
}

\author{
Tinde van Andel ${ }^{\text {Corresp., } 1,2,3}$, Rutger A. Vos ${ }^{2}$, Ewout Michels ${ }^{2,3}$, Anastasia Stefanaki ${ }^{1,2}$ \\ 1 Biosystematics group, Wageningen University and Research, Wageningen, The Netherlands \\ 2 Naturalis Biodiversity Center, Leiden, the Netherlands \\ 3 Institute for Biology, Leiden University, Leiden, the Netherlands \\ Corresponding Author: Tinde van Andel \\ Email address: tinde.vanandel@naturalis.nl
}

Background. Soon after the Spanish conquest of the Americas, the first tomatoes were presented as curiosities to the European elite and drew the attention of sixteenth-century Italian naturalists. Despite of their scientific interest in this New World crop, most Renaissance botanists did not specify where these 'golden apples' or 'pomi d'oro' came from. The debate on the first European tomatoes and their origin is often hindered by erroneous dating, botanical misidentifications and inaccessible historical sources. The discovery of a tomato specimen in the sixteenth-century 'En Tibi herbarium' kept at Leiden, the Netherlands, triggered research on its geographical provenance and morphological comparison to other tomato specimens and illustrations from the same time period.

Methods. Recent digitization efforts greatly facilitate research on historic botanical sources. Here we provide an overview of the ten remaining sixteenth-century tomato specimens, early descriptions and 13 illustrations. Several were never published before, revealing what these tomatoes looked like, who saw them, and where they came from. We compare our historical findings with recent molecular research on the chloroplast and nuclear DNA of the 'En Tibi' specimen.

Results. Our survey shows that the earliest tomatoes in Europe came in a much wider variety of colors, shapes and sizes than previously thought, with both simple and fasciated flowers, round and segmented fruits. Pietro Andrea Matthioli gave the first description of a tomato in 1544, and the oldest specimens were collected by Ulisse Aldrovandi and Francesco Petrollini in c. 1551, possibly from plants grown in the Pisa botanical garden by their teacher Luca Ghini. The oldest tomato illustrations were made in Germany and Switzerland in the early 1550s, but the Flemish Rembert Dodoens published the first image in 1553. The names of early tomatoes in contemporary manuscripts suggest both a Mexican and a Peruvian origin. The 'En Tibi' specimen was collected by Petrollini around 1558 and thus is not the oldest extant tomato. Recent molecular research on the ancient nuclear and chloroplast DNA of the En Tibi specimen clearly shows that it was a fully domesticated tomato, and genetically close to three Mexican landraces and two Peruvian specimens that probably also had a Mesoamerican origin. Molecular research on the other sixteenth-century tomato specimens may reveal other patterns of genetic similarity, past selection processes, and geographic origin. Clues on the 'historic' taste and pest resistance of the sixteenthcentury tomatoes will be difficult to predict from their degraded DNA, but should be rather sought in those landraces in Central and South America that are genetically close to them. The indigenous farmers growing these traditional varieties should be supported to conserve these heirloom varieties in-situ. 


\section{Sixteenth-century tomatoes in Europe: who saw them,}

2 how they looked like, and where they came from

3

4

Tinde van Andel ${ }^{1,2,3}$, Rutger $\operatorname{Vos}^{1}$, Ewout Michels ${ }^{1,2}$, Anastasia Stefanaki ${ }^{1,3}$

${ }^{1}$ Naturalis Biodiversity Center, Leiden, the Netherlands.

${ }^{2}$ Institute for Biology, Leiden University, Leiden, the Netherlands.

${ }^{3}$ Biosystematics group, Wageningen University, Wageningen, the Netherlands

Corresponding Author:

Tinde van Andel

Darwinweg 2, 2333 CR Leiden, the Netherlands

Email address: tinde.vanandel@naturalis.nl

\section{Abstract}

Background. Soon after the Spanish conquest of the Americas, the first tomatoes were presented as curiosities to the European elite and drew the attention of sixteenth-century Italian naturalists. Despite of their scientific interest in this New World crop, most Renaissance botanists did not specify where these 'golden apples' or 'pomi d'oro' came from. The debate on the first European tomatoes and their origin is often hindered by erroneous dating, botanical misidentifications and inaccessible historical sources. The discovery of a tomato specimen in the sixteenth-century 'En Tibi herbarium' kept at Leiden, the Netherlands, triggered research on its geographical provenance and morphological comparison to other tomato specimens and illustrations from the same time period.

Methods. Recent digitization efforts greatly facilitate research on historic botanical sources. Here we provide an overview of the ten remaining sixteenth-century tomato specimens, early descriptions and 13 illustrations. Several were never published before, revealing what these tomatoes looked like, who saw them, and where they came from. We compare our historical findings with recent molecular research on the chloroplast and nuclear DNA of the 'En Tibi' specimen.

Results. Our survey shows that the earliest tomatoes in Europe came in a much wider variety of colors, shapes and sizes than previously thought, with both simple and fasciated flowers, round and segmented fruits. Pietro Andrea Matthioli gave the first description of a tomato in 1544, and the oldest specimens were collected by Ulisse Aldrovandi and Francesco Petrollini in c. 1551, possibly from plants grown in the Pisa botanical garden by their teacher Luca Ghini. The oldest tomato illustrations were made in Germany and Switzerland in the early 1550s, but the Flemish Rembert Dodoens published the first image in 1553 . The names of early tomatoes in 
40 contemporary manuscripts suggest both a Mexican and a Peruvian origin. The 'En Tibi'

41 specimen was collected by Petrollini around 1558 and thus is not the oldest extant tomato.

42 Recent molecular research on the ancient nuclear and chloroplast DNA of the En Tibi specimen 43 clearly shows that it was a fully domesticated tomato, and genetically close to three Mexican

44 landraces and two Peruvian specimens that probably also had a Mesoamerican origin. Molecular 45 research on the other sixteenth-century tomato specimens may reveal other patterns of genetic 46 similarity, past selection processes, and geographic origin. Clues on the 'historic' taste and pest 47 resistance of the sixteenth-century tomatoes will be difficult to predict from their degraded DNA, 48 but should be rather sought in those landraces in Central and South America that are genetically 49 close to them. The indigenous farmers growing these traditional varieties should be supported to 50 conserve these heirloom varieties in-situ. 


\section{Introduction}

53 Soon after Christopher Columbus' first voyage to the Americas, the first New World crops were taken to Europe as curiosities and presented to the royal courts (Pardo Tomás \& López Terrada, 1993; Katz, 2009). Seeds of maize, marigold and chili peppers were planted in noblemen's gardens as exquisite novelties, where they attracted the interest of early sixteenth-century scholars (Daunay, Laterrot \& Janick, 2007; Egmond, 2016). One of the American crops that travelled from indigenous farms through the hands of Spanish colonizers to European aristocrats' gardens was the tomato (Solanum lycopersicum L.). After the conquest of the Aztec city of Tenochtitlan (now Mexico City) in 1521 by Hernán Cortez, the Franciscan friar and chronicler Bernardino de Sahagún (c. 1577: 49) reported that the Aztecs cultivated a great variety of tomatoes of different sizes, shapes and colors. The Spanish later adopted their Nahuatl term tomatl as tomate (Long, 1995).

64

The port of Seville was the principal point of entry for products from the New World (Jenkins, 1948; Rotelli, 2018). Still, there is no record of the introduction of the tomato in this Spanish port, or its cultivation in the royal Iberian gardens (Jenkins, 1948), as plant transfers were rarely considered important enough to document (Long, 1995). Due to the many Italian merchants sailing under Portuguese and Spanish flags, and the fact that the Kingdom of Naples was under Spanish rule, these new exotic plants quickly reached Italy (Rotelli 2018). Soon after the first tomato seeds sprouted in the gardens of Italian aristocrats in the 1540s, they became the object of study by Renaissance naturalists, who described and depicted these 'golden apples' with great interest (Daunay, Laterrot \& Janick, 2007; Egmond, 2018). From an unknown aphrodisiac to an essential ingredient in national dishes, the subsequent European history of the tomato has been extensively studied (e.g., Sturtevant, 1919; McCue, 1952; Gentilcore 2010; Metro-Roland, 2013).

Despite their scientific interest in this recently introduced crop, most sixteenth-century botanists did not specify where their tomatoes came from. An exception was the Venetian naturalist Pietro Antonio Michiel, who mentioned that the fruits were known as 'love apples' by some and as 'Peruvian apples' by others (Poma amoris da alcuni et del Peru, De Toni, 1940). Although Jenkins (1948) classified the latter name as dubious, it gave rise to the alternative hypothesis that the first European tomatoes were brought from Peru, shortly after Francisco Pizarro's conquest of the Inca emperors in 1531 (Bailey, 1886; Peralta, Spooner \& Knapp, 2008).

The geographic origin of tomato domestication has been debated for at least two centuries (Klee and Resende, 2020). Evidence for the 'South American theory' was provided early on by the discovery of wild relatives of tomato along the coastline between Ecuador and northern Chile (Jenkins, 1948; Peralta, Spooner \& Knapp, 2008). Molecular studies have demonstrated a high genetic and morphological diversity of traditional tomato varieties on the eastern slopes of the

91 Andes in Ecuador and Peru (Blanca et al., 2015; Knapp \& Peralta, 2016), but the Mexican origin 
92 of the cultivated tomato was still considered (Peralta \& Spooner 2007). The current model for the 93 tomato domestication process is that the small-fruited Solanum lycopersicum var. cerasiforme

94 (Dunal) D.M.Spooner, G.J.Anderson \& R.K.Jansen originated from the red-fruited wild species

95 S. pimpinellifolium L, which spread slowly northwards from the Peruvian desert to Mesoamerica,

96 adapting itself gradually to wetter environments, unrelated to human activity (Blanca et al.,

97 2021). Later, indigenous people took the wild Mexican cherry-sized tomato to South America,

98 where it was domesticated, and brought it back to Mesoamerica, where they further domesticated

99 it into the very variable big-fruited S. lycopersicum L. var. lycopersicum (Blanca et al., 2021;

100 Blanca 2021). Details on the exact time and place of domestication of the tomato are still not

101 known with certainty for either Mexico, Ecuador or Peru (Bai \& Lindhout, 2007), but there is a

102 diminishing genetic diversity from Ecuador to Mexico (Lin et al., 2014; Blanca et al., 2015).

103

104

105

In 1989, Sergio Toresella, an expert on medieval herbals, examined a well-preserved tomato

106 specimen in a sixteenth-century book herbarium kept at Naturalis Biodiversity Center in Leiden, the Netherlands. He claimed that this plant collection was made in Ferrara (Italy) between 1542 and 1544 and therefore was the oldest existing herbarium (Toresella, 1992). This meant that the anonymous Italian maker of this 'En Tibi herbarium' had collected the earliest European tomato specimen (Houchin, 2010; Thijsse, 2012; Egmond, 2016). As such, the collector would have predated compatriots Pietro Andrea Matthioli, who described a 'new species' in his section on mandrake in 1544 (McCue, 1952), and naturalist Ulisse Aldrovandi, who collected in 1551 a specimen of a cultivated tomato, preserved at the Bologna Herbarium, that was considered as the earliest extant specimen (Peralta, Spooner \&Knapp, 2008).

The Leiden specimen was also thought to be older than a tomato in a herbarium in Rome, dated pre-1553 (De Toni, 1910), which was attributed first to the painter Gherardo Cibo (Penzig, 1905) and later to the physician Francesco Petrollini (Chiovenda, 1909). However, the 'En Tibi

119 https://data.biodiversitydata.nl/naturalis/specimen/L.2111092), did not resemble the well-known sixteenth-century woodcut illustration of a tomato plant with double flowers and elongated, segmented fruits, claimed as typical for the early European tomatoes (Sturtevant, 1919; Daunay, Laterrot \& Janick, 2007). This woodcut is often inaccurately attributed to Matthioli (e.g., Houchin, 2010), but was published eight years after his death by Camerarius in his commentaries on Matthioli, first in black and white (1586) and four years later in color (Camerarius, 1586: 821; 1590: 378). In the Aldrovandi manuscripts, kept at the University of Bologna, there is an undated list of seeds sent by Aldrovandi to Camerarius that mentions 'Pomum amoris flore rubro non compressum' (Aldrovandi manuscripts 136 VII, c. 26).

128

129 The finding of the 'oldest extant tomato' in the Netherlands led to claims in the popular media 130 that the DNA of this 'primitive tomato' could disclose potential ancient resistances to pests and 131 diseases lacking in modern crops. It was suggested that the En Tibi tomato could help plant 
132 breeders develop new cultivars with the 'original taste' of the sixteenth-century tomatoes (Van

133 Santen, 2012; De Boer, 2013). The genomic diversity stored in herbarium specimens creates

134 ample opportunities for genome-scale population and domestication studies (Staats et al., 2013).

135 Comparing the DNA of traditional crop specimens to the increasingly available online genetic

136 information on crop accessions worldwide can also provide detailed information on geographic

137 origins, past selection processes and historic migration routes of plants and people (van Andel et

138 al., 2016; Larranaga, van Zonneveld \& Hormaza, 2021). Unfortunately, the sampling of

139 historical collections has had limited success due to their highly degraded DNA, although

140 significant progress is being made with new 'ancient genomics' methods (Bakker et al., 2020).

At the same time, ongoing digitization efforts greatly facilitate the research on sixteenth-century herbaria, illustrations, publications and manuscripts (Koning et al., 2008; Van Andel, 2017).

144 However, the literature on early tomato descriptions and depictions often lacks detailed links to the original sources. The latter can now be directly inspected online and sometimes reveal other authors, editions, dates and species than previously thought. Our recent revision of the En Tibi herbarium uncovered that it was not made in Ferrara in 1542-3 as had been suggested, but in Bologna around 1558 by the Italian botanist Francesco Petrollini, who also made the so-called 'Erbario Cibo' kept in Rome (Stefanaki et al., 2018; 2019).

This paper aims to provide a more accurate overview of early sixteenth-century descriptions, illustrations and particularly herbarium specimens of the tomato. Some of the published sources have been digitally available for some years, but several images and most of the herbarium specimens have never been published so far. We show that the earliest tomatoes in Europe came in a variety of colors, shapes and sizes, and reveal that some 'early tomatoes' were, in fact, misidentified and represent other, related species. We compare these findings with recent molecular research on 'En Tibi' specimen's nuclear DNA (Michels, 2020) and choloroplast DNA (Kakakiou, 2021), which shed new light on its probable geographic origin.

\section{Materials \& Methods}

We performed a literature review, starting with studies on the introduction of the tomato in Europe (e.g., Jenkins, 1948. McCue, 1952, Daunay, Laterrot \& Janick, 2007; Gentilcore, 2010) and on early modern naturalists in Italy, France, Central Europe and the Low Countries (e.g., De Toni, 1907, 1910, 1940; Findlen, 1994, 2017; Egmond, 2016, 2018, Rotelli, 2018.). We also reviewed modern taxonomic and molecular studies on the origin of the tomato (e.g., Peralta, Spooner \& Knapp, 2008; Lin et al., 2014; Blanca et al., 2021). We consequently traced the original sixteenth-century manuscripts cited in these works via online repositories (e.g., google books, the Biodiversity Heritage Library, https://www.europeana.eu).

170 We searched for tomato specimens in sixteenth-century herbaria (for an overview of the c. 32 
172 studies on these historical collections (e.g., Kessler, 1870; Caruel, 1858; Camus \& Penzig, 1885;

173 Penzig, 1905; Speta \& Grims, 1980; Soldano, 2000). Where available, we checked the published

174 species lists, and otherwise the indices and specimens of these herbaria, for references to 'pomo',

175 'mala', 'lycopersicon', 'Lycopersicum', 'Solanum', etc. We approached several libraries and

176 museums in Italy, France, Germany, Poland and Switzerland to request digital images of

177 specimens and illustrations in manuscripts that had not yet been published. We provided links to

178 digital sources of the historical specimens, literature, manuscripts and images that we reviewed

179 for this study. We listed the local and pre-Linnaean scientific names for tomatoes mentioned in

180 the original published sources, manuscripts, and handwritten texts on botanical vouchers,

181 illustrations or herbarium labels. We checked each historical specimen, description and depiction

182 for visible or written evidence of different shapes, sizes and colors of flowers and fruits. We

183 scrutinized all historical material for possible clues of the geographical origins of the tomatoes.

184 Finally, we report on two recent molecular studies on the genetic affinities of the sixteenth-

185 century tomato specimen in the En Tibi herbarium (Michels, 2020; Kakakiou, 2021).

186

187 Results

188 The first mention of a tomato (1544)

189 In 1544, the Italian physician and botanist Pietro Andrea Matthioli (1501-1578) was the first

190 person to mention the tomato in Europe, in the first edition of his commentary in Italian on the

191 famous classical herbal De Materia Medica by Pedanius Dioscorides (c. 60 AD), entitled: ' $D i$

192 Pedacio Dioscoride Anazarbeo libri cinque della historia, et materia medicinale trodotti in

193 lingua volgare Italiana'. In his chapter on mandrake (Mandragora), he adds: "Another species

194 [of eggplant, Solanum melongena L.] has been brought to Italy in our time, flattened like the

195 mele rose [a type of apple] and segmented, green at first and when ripe of a golden color, which

196 is eaten in the same manner [as the eggplant: fried in oil with salt and pepper, like mushrooms]"

197 (Matthioli, 1544: 326). Matthioli's first publication is not available online, so we relied on the

198 translation by McCue (1952). Unfortunately, there is no illustration. The second edition

199 (Matthioli, 1548) had the same text and still did not mention any local name for the tomato.

200 Matthioli's work became a bestseller, selling over 30,000 copies, and he constantly enlarged the

201 book with augmented editions (Palmer, 1985). In 1554, Matthioli translated his commentary in

202 Latin, expanding his text about the tomato, which he described after the eggplant: "Another

203 species has already begun to be imported, flattened, round like apples, ribbed like melons, at first

204 green, in some plants turning gold and in others red. They are colloquially called pomi d'oro,

205 that is, mala aurea. Eaten in the same way [as eggplant with oil, salt and pepper, like

206 mushrooms. That said by Hermolao]" (Matthioli, 1554: 479). With his phrasing, Matthioli

207 suggested that there were multiple introductions of tomato over a longer period of time, with

208 different colors and shapes. The same text appears after the description of the melanzane

209 (eggplant) in many of the later versions of his book, named pomi d'oro in the Italian and mala

210 aurea in the Latin editions. Unfortunately, Matthioli has never produced or commissioned an

211 image of a tomato during his life (Table 1). 
212

213 But where did Matthioli see his first tomato? According to Ubriszy Savoia (1993), his (former)

214

215

216

217

218

219

220

221

222

223

224

225

226

227

228

229

230

231

232

233

234

235

236

237

238

239

240

241

242

243

244

245

246

247

248

249

250

251 teacher Luca Ghini (c. 1490-1556) had obtained the seeds from the Venetian patrician and naturalist Pietro Antonio Michiel (1510-1576). Next to his house in Venice, Michiel cultivated numerous exotic plants from faraway places, including the Americas, the Near East and northern Africa. His objective was to spread these botanical novelties among his network, so he sent seeds and sprouts of plants to his friends (De Toni, 1940). Michiel was given the charge to curate the Padua garden from 1551 to 1555 when Luigi Squalermo (1512-1570), better known as Anguillara, was prefect. Anguillara had followed Ghini's classes and worked in his teacher's private garden in Bologna, and in 1546 became the first prefect of the Padua garden (Minelli, 2010). In 1543, Anguillara assisted Ghini in amassing materials for the Pisa garden (Findlen, 2017), so it is more likely that Anguillara (and not Michiel) provided Ghini with tomato seeds, also because the Padua garden was founded in 1545 (Palmer, 1985), a year after Matthioli described the first European tomato. Michiel apparently started to expand his Venice garden upon his return from Padua in 1555 (De Toni, 1940).

Ghini taught medical botany in Pisa from 1544 to 1555, where he founded the first university botanical garden supported by the Grand Duke of Tuscany, Cosimo I de' Medici (De Toni, 1907). Cosimo attempted to import and acclimatize various American plants (Gentilcore, 2010), and Ghini enriched the garden with exotic species and taught his many pupils to press and dry botanical specimens between paper (Findlen, 2017). According to McCue (1952: 292), the Pisa garden catalogue manuscript from 1548 'does not include any plant identifiable as the tomato'. However, the inventory of this catalogue brought to light by De Toni (1907: 439) lists a plant named 'Thumatulum pomum vulgo dictum rubrum et luteum' (Table 1) and suggests that the catalogue with 620 species could have been started already in 1545 .

Matthioli did not travel much after he reached his forties (from 1541 onwards he stayed in the small town of Gorizia, near the current border with Slovenia) and simply sent lists of Dioscoridean plants that he had not yet seen or identified to his colleagues (Palmer, 1985). He often included the knowledge of his fellow scientists or local people in the many editions of his books without citing them (Arber, 1986). Ghini had sent many dried specimens to Matthioli, accompanied by written opinions on their identification (De Toni, 1907; Palmer, 1985). If Ghini had already planted his first tomato seeds in the Pisa garden in 1544 (Ubriszy Savoia, 1993), it was likely his description of the tomato that ended up in Matthioli's first edition of his Commentaries on Dioscorides in 1544.

\section{The first tomato specimen (1551)}

One of Ghini's best-known disciples was Ulisse Aldrovandi (1522-1605), who became famous for his 16-volume herbarium with over 4000 specimens kept at the botanical garden in Bologna. The tomato specimen is preserved in the first volume (Fig. 1A), which Aldrovandi started in 
252 1551, and is therefore considered the oldest extant botanical voucher of this New World crop

253 (Table 1). Thorough work has been carried out to trace the origin of Aldrovandi's specimens, but

254 unfortunately for the tomato specimen this information has not survived (Soldano, 2000).

255 Aldrovandi kept an extensive correspondence with other naturalists. From his letters, we know

256 that around 1551, plants were sent to him by Michiel, then employed in the Padua botanical

257 garden (Minelli, 2010), by Ghini from the Pisa garden (Ubriszy Savoia, 1993) and by his

258 companion and guide in the field Francesco Petrollini (Soldano, 2000; Stefanaki et al., 2019).

259

260 Petrollini, whose birth and death dates remain unknown, also attended classes by Ghini and

261 graduated in Bologna in 1551. Two of his tomato specimens have survived: one in his extensive

262

263 work herbarium, which is known to have consisted of several book volumes by 1553 (De Toni, 1910) and is kept in the Bibliotheca Angelica in Rome, and one in the En Tibi herbarium (c.

264 1558) that was made on commission, possibly for the Habsburg emperor Ferdinand I (Stefanaki et al., 2019). The tomato specimen in the Rome herbarium has immature fruits. A separate fruit glued on top of the page, partly destroyed by insects, is an immature eggplant and belongs to another specimen (Fig. 1B). We know that Petrollini graduated two years before Aldrovandi and guided him in his early steps in the field. It is, therefore, likely that he started his work herbarium earlier than Aldrovandi (De Toni, 2010), but the tomato appears only in the third volume. The tomato in the En Tibi herbarium is thus not the oldest preserved tomato specimen in the world, although it is the earliest surviving specimen with (the remains of) a mature fruit (Fig. 1C).

272

273

274

We traced 17 surviving sixteenth-century herbaria in Italy, Germany, France, Switzerland and

275 the Netherlands (Supplementary Table 1), eight of which contain tomato specimens (Fig. 1A-J). We have no indication of tomato specimens in other surviving herbaria produced in this time period. The oldest extant herbarium was compiled by Michele Merini, also a pupil of Ghini, in

277

278 the Pisa botanical garden between 1540-1545. His herbarium is not available online, but its contents were published by Chiovenda (1927), and it does not contain a tomato specimen.

279 Another disciple of Ghini, Andrea Cesalpino, also made a herbarium in the Pisa garden between 1555-1563. Although he mentions the tomato in his De plantis Libri XVI (Cesalpino, 1583), there is no tomato among his vouchers (Caruel, 1858). The first herbaria made in France (by

282 Jehan Girault in 1558) and the Low Countries (by Petrus Cadé in 1566, see Christenhusz, 2004)

283 do not have a tomato specimen either. The second herbarium produced in France, that of the German botanist Leonhard Rauwolf, contains a tomato (Fig. 1D), but this specimen was collected during Rauwolf's field trip in northern Italy in 1563 (Stefanaki et al., 2021). Tomato specimens are also included in the herbaria Estense (Ferrara, Italy), Bauhin (three specimens; Harder (Ulm, Germany); all these collections have been compiled towards the end of the sixteenth century (Supplementary Table 1, Fig. 1A-J).

290

\section{The first image of a tomato (1553)}


292

293

294

295

296

297

298

299

300

301

302

303

304

305

306

307

308

309

310

311

312

313

314

315

316

317

318

319

320

321

322

323

324

325

326

327

328

329

330

331

Although the tomato was common in Mexico at the time of the Spanish conquest, no images of tomatoes made in the New World exist (Daunay, Laterrot \& Janick, 2007). An uncolored woodcut illustration, published in 1553 in a Latin herbal by the Flemish doctor and botanist Rembert Dodoens, can be considered the first image of a tomato (Fig. 2A). A year later (Dodoens, 1554), he published a colored version of the same woodcut (Fig. 2B). Also known under his Latinized name Dodonaeus, Dodoens studied at several universities and travelled to France, Germany and Italy from 1535 to 1546, where he may have seen the tomato for the first time. In 1548, he settled in Mechelen (currently Belgium), then a hotspot of sixteenth-century naturalists, who studied exotic plants in the gardens of local noblemen. In a later edition of his herbal, Dodoens (1583) acknowledged the people who supplied him with plants. One of them, Jean de Brancion, had a beautiful garden with many exotic species, obtained via his extensive international network (Egmond, 2010). In Aldrovandi's manuscripts, kept at the University of Bologna, there are several lists of seeds sent to De Brancion (Frati, Ghigi \& Sorbelli, 1907), of which one, dated 10 January 1571, contains a 'Pomum pomiferum' listed just before the eggplant, indicated as 'Mala insane purpurea' (Aldrovandi manuscripts $136 \mathrm{~V}$, c. 137v). Another possibility is that Dodoens obtained a tomato plant from the garden of the Antwerp apothecary Pieter van Coudenberghe, created in 1548 and containing more than 600 exotic plants (Vandewiele, 1993).

On 22 September 1553, in the same year that Dodoens published the first woodcut, two tomato plants were depicted by the Swiss naturalist Conrad Gesner (Table 1, Fig. 2C-D). Unfortunately, his Historia Plantarum, a beautiful collection with hundreds of colored plant illustrations, was never published. Gesner had travelled to Italy in 1544, where he met Ghini to study his collections (Findlen, 2017), which provides us with a clue to where he may have obtained his tomato seeds. Later, Gesner (1561) wrote that the tomato was grown by Pieter van Coudenberghe in Antwerp (a possible source of Dodoens' tomato), by Vuoysselus in Breslau (now Poland) and in German gardens by Joachimus Kreichius in Torgau and in Nuremberg by George Oellinger. Apothecary Oellinger (Ollingerus) also had three drawings made by Samuel Quichelberg (1529-1567) of the different tomato varieties that he had planted (Fig. 2G-I). His vast collection of naturalist drawings, Magnarum medicinae partium herbariae et zoographiae, was finished in 1553 but never published until Lutze and Retzlaff (1949) published a selection of his work.

In the meantime, from c. 1550 to his death in 1576, the Venetian nobleman Michiel worked on his garden inventory, finalized in a five-volume illustrated manuscript now held by the Marciana library in Venice (De Toni, 1940). Michiel attempted to describe all plants he knew, so the species that figure in his work may have grown in the Padua garden, in his own Venice estate, or they were sent to him as dried specimens (De Toni, 1940). The third volume (Libro Rosso I) features a description of the tomato (Table 1). When he started his manuscript, Michiel was still in Padua and may have seen the tomato there. The watercolor image in this manuscript is 
332 possibly made by Domenico Dalle Greche (Fig. 2F). Another drawing in Michiel's manuscript

333 (Supplementary Fig. 1) was mentioned as one of the earliest depicted tomatoes in Europe

334 (Egmond, 2018), but the depicted plant has simple, lobed leaves and symmetrical, depressed and

335 deeply furrowed fruits. We agree with De Toni's identification of this illustration as an Ethiopian

336 eggplant (Solanum aethiopicum L.), probably a member of the kumba cultivar group (PROTA,

337 2015).

338

339 Another candidate for the earliest extant European drawing of the tomato is a watercolor image

340 (Fig. 2E) in a manuscript by the German botanist Leonhart Fuchs, dated between 1549 and 1561

341 and known as the 'Vienna Codex' (Meyer, Trueblood \& Heller, 1999; Baumann, Baumann \&

342 Baumann-Schleihauf, 2001). This manuscript was meant to become an extended version of his

343 famous herbal De historia stirpium commentarii insignes (Fuchs, 1542), widely considered a

344 masterpiece with 500 very accurate woodcut illustrations and the first known European

345 publication of New World plants such as maize, tobacco, marigold and chili pepper (Meyer,

346 Trueblood \& Heller, 1999). The tomato, however, was not yet described in this famous herbal,

347 nor its later editions. It does appear in the Vienna Codex as a drawing (Fig. 2E) and in the text,

348 which reported that this unfamiliar 'apple' was only known from gardens and that it was not

349 mentioned by the ancient Greeks, Romans or even the Moors. The manuscript was never

350 published, but Meyer, Trueblood \& Heller (1999) suggested that the drawing may be earlier than

351 the woodcut of Dodoens (1553).

352

353

354

355

356

357

358

359

360

In 1586, decades after the first tomato illustrations in the 1550s and eight years after Matthioli's death in 1578, an uncolored woodcut of a tomato plant (Fig. 2M) appeared in De Plantis Epitome Utilissima, an enlargement of Matthioli's work published in Latin by Joachim Camerarius (1586: 821). A colored version of the same woodcut (Fig. 2N) is published four years later, again by Camerarius, but this time in German (1590: 378), although this image is often attributed to Matthioli (e.g., Houchin, 2010).

The first names of tomatoes

361 In 1548, Grand Duke Cosimo I was presented some tomatoes from his Florentine Estate. A letter

362 from 1548 mentions that the Florentine pomidoro arrived safely at the ducal household (Table 1).

363 This letter is the earliest written evidence of the term 'golden apples' in Italian (Gentilcore,

364 2010). The Latin translation of this local name ('mala aurea') quickly follows in 1554, while

365 Aldrovandi's name 'mali insani' refers to its resemblance to the botanically related eggplant or

366 melanzana (Table 1). Other early sixteenth-century names of the tomato reveal that it came in

367 different colors (red, golden, brown, yellow) or that it was related to the mandrake

368 ('Mandragorae species').

369

370

The terms 'pomum amoris' or 'pomme d'amour' are often said to refer to the alleged aphrodisiac

371 properties of the tomato (Smith, 1994). The French term was likely added by a French translator 
372 of Matthioli's work (Peralta, Spooner \& Knapp, 2008) and could also be a corruption of 'pome 373 dei Moro' (apples of the Moors, Houchin 2010) or 'pomi d'oro'. Two years before Matthioli's

374 first description of the tomato in 1544, the term 'amoris poma' was already coined by Fuchs

375 (1542: 532) in his description of the eggplant. Michiel also described the eggplant as 'Pomes da 376 mouri da Galli, Melongena da Arabi', a fruit brought by the Moors or Arabs (De Toni, 1940).

377 Solanum melongena L. was indeed introduced to Europe during the Middle Ages by Arab traders 378 from India (Daunay, Laterrot \& Janick, 2007).

379

380

381

382

383

384

385

386

387

388

389

390

391

392

393

394

395

396

397

398

399

400

401

402

403

404

405

406

407

408

409

410

411

The Spanish gave the name 'love apple' first to the Mexican tomatillo (Physalis ixocarpa Lam.), of which the calyx splits open to reveal the fruit, apparently reminding them of female genitals. Later the Spanish transferred this name to the tomato (Gentilcore, 2010). Although the Italians never adopted the Spanish name 'tomate', derived from the Nahuatl 'tomatl' (Long, 1995), the appearances of 'thumatulum' in the inventory of the Pisa garden, 'tumatl' in the inventory of the Bologna garden and 'Tumatle Americanorum' in Guilandinus (1572), successor of Anguillara in the Padua garden, suggest that some early modern botanists knew this name. However, the local term 'poma/pomo' was more common (Table 1).

The name 'Saliunca' in the En Tibi herbarium was erroneously given to the tomato specimen, a mistake made by the scribe who wrote the plant names next to the specimens: the name was meant for the preceding specimen (nr. 293) of Valeriana celtica L. (Stefanaki et al., 2018). According to Ubriszy Savoia (1993: 581), Aldrovandi's term 'Tembul quibusd.' (another type of Tembul) refers to Solanum betaceum Cav., the South American tree tomato, but this species was only introduced in European botanical gardens in 1836.

The remark that 'some people knew the tomatoes as Peruvian apples' was made both by Michiel (De Toni, 1940) and Anguillara (1561), which is not surprising as they were friends and worked together in the Padua garden from 1551 to 1555 (Minelli, 2010). Several other Andean plants figure in Michiel's garden inventory (De Toni, 1940), such as coca (Erythroxylum coca Lam.) and 'quina de India' (probably Cinchona sp.). As Michiel never published his garden inventory, Anguillara (1561) was quoted for this South American provenance by C. Bauhin in his annotated edition of Matthioli's commentaries (C. Bauhin 1598: 761, Table 1). According to Jenkins (1948), however, there is nothing in the historical record that suggests a Peruvian origin of the tomato. Nevertheless, De Candolle (1885) argued that sixteenth century botanists had received the plant from Peru. De Candolle based this on J. Bauhin \& Cherler (1651, published posthumously) who mentioned the name 'Pomi del Peru' as a vernacular Italian name. They also mentioned the name 'Mala Peruviana', citing Hortus Eystetensis (Besler, 1613) as the source, but this name is not mentioned in the tomato illustration in this book. Gray \& Trumbull (1883) assume that Anguillara mistook the tomato for Datura stramonium L., an American Solanaceae described as 'mala peruviana' by Guilandinus (1572). Despite his closeness to Ghini, there is no evidence that Anguillara made a herbarium, so no specimen of the 'Poma del Peru' exists. In the

Peer) reviewing PDF | (2021:04:59968:2:0:NEW 25 Nov 2021) 
412 extensive collection of Aldrovandi's manuscripts, however, there are many lists of objects

413 (plants, animals, minerals) that he received from all over the world, including South American

414 locations such as the Tumbes province in Peru, the Ecuadorian capital Quito, Cumana

415 (Venezuela) and Uraba in Colombia (Frati, Ghigi \& Sorbelli, 1907). It is unfortunately unknown

416 whether Aldrovandi received his tomato specimen directly from his contacts overseas and, if so,

417 from which location. Guilandinus (1572) referred to the tomato as 'tumatle', using its Nahuatl

418 name, and wrote that it came from 'Themistithan', according to Jenkins (1948) a corruption of

419 Tenochtitlan, the Aztec name for what is now Mexico City. Aldrovandi also made a

420 'Themistitani catalogus' of natural objects received from this area, next to lists of specimens

421 from other Mexican locations such as 'Iztapalapa', 'Jucatan insula' and 'Tlaxcala' (Frati, Ghigi

$422 \&$ Sorbelli, 1907: 181). Still, we do not know whether tomatoes are listed in these manuscripts.

423

424 The name 'Ethiopian apple' written next to the tomato specimen in the anonymous Ducale

425 Estense herbarium (Fig. 1I, Table 1) refers to an African origin. This demonstrates the existing

426 confusion between Solanum lycopersicum and the related Old-World species S. aethiopicum,

427 also depicted in Michiels manuscript (Supplementary Fig. 1). Besides the tomato specimens,

428 there are also three specimens of S. aethiopicum in C. Bauhins' herbarium, one of which was

429 named 'poma amoris racemosa' and possibly came from his own garden (Supplementary Fig. 2).

430 The word 'Ettiopia' or 'aethiopicum' in those days did not refer to the current country of

431 Ethiopia but was used as a general term to indicate the African continent (De Toni, 1940).

432

433 The name Lycopersicon means 'wolf peach', after the Greek words for wolf (lykos) and peach

434 (persikon), and was first used by the Greek physician Galen (AD 131-200) for designating a

435 plant from Egypt with malodorous sap, just like tomato leaves. Which species Galen had in mind

436 while describing the wolf peach has been lost in centuries of translations and misinterpretations

437 of the classical texts during the Middle Ages (Palmer, 1985). Galen had never seen any New

438 World plant, but a major aim of the Renaissance naturalists was to search for plant specimens

439 that matched descriptions by the classical authors (Palmer, 1985; Stefanaki et al., 2019).

440 However, the German botanist Fuchs argued in his manuscript that as the Greek and Latin

441 authors did not mention the tomato, the plant should not carry any of the classical names (Meyer,

442 Trueblood \& Heller, 1999). The Greek name was used in Latin as specific epithet of Solanum

443 lycopersicum L. by Linnaeus (1753), after which Miller (1754) applied it as the genus name for

444 the cultivated tomato (Lycopersicum esculentum Mill). Modern taxonomy has brought the

445 tomato back to the genus Solanum (Peralta, Spooner \& Knapp, 2008). Another attempt of

446 sixteenth-century naturalists to trace the tomato in ancient literature led them to the 'Glaucium'

447 of Dioscorides: De Lobel $(1571,1576)$, for example, described, not without doubts, the tomato

448 under poppies.

449

450

\section{The morphology of early tomatoes}


451 The woodcut illustration of the elongated, segmented tomatoes by Camerarius $(1586 ; 1590)$

452 became widely known, as Matthioli's Commentaries on Dioscorides continued to be a bestseller

453 after his death. However, the sixteenth-century herbarium specimens and the images of small

454 spherical tomatoes in unpublished manuscripts remained locked up in royal treasure rooms,

455 libraries, and universities. This has led to the idea that the earliest tomatoes introduced to Europe

456 were 'large and lumpy', a 'mutation' from a smoother, more diminutive Mesoamerican form,

457 and probably 'the direct ancestor of some modern cultivated tomatoes' (Smith, 1994:15).

458 According to Sturtevant (1919), there were no indications that the round tomato was known

459 among the early botanists before 1700 .

460

461

462

From our review of the sixteenth-century descriptions, images and herbarium specimens, it

463 becomes clear that different landraces of tomatoes were introduced early on in Europe. These represented a great variety in flower and fruit shape, size and color, as was already suggested by Daunay, Laterrot \& Janick (2007) and Peralta, Spooner \& Knapp (2008). Several tomato illustrations (e.g., Camerarius, 1586) and specimens like those of C. Bauhin (Fig. 1E-G) show duplications of sepals and petals, exserted styles and deeply furrowed (segmented) fruits, while the specimens in the En Tibi and Rauwolf herbaria (Fig. 1C-D) and Oellinger's third drawing (Fig. 2I) have simple flowers (5 petals) and small, spherical fruits (Table 2).

469

470

Although the drawing in Fuchs' manuscript (Vienna Codex, 1549-1556/1561) is often

471 considered 'unnatural' and 'false' (Meyer, Trueblood \& Heller, 1999; Koning et al., 2008), the

472 task assigned to artist Albrecht Meyer was to represent the variation in flowers and fruits, instead of depicting an individual plant. Fuchs wrote that he had seen at least three different varieties and decided to include all in one illustration (Meyer, Trueblood \& Heller, 1999: 629; Peralta, Spooner \& Knapp, 2008). Dominico dalle Greche also included several fruit types in his drawing for Michiel (Fig. 2F). According to McCue (1952), the reference by Cesalpino (1583) to the white color of the flowers was incorrect, but Camerarius (1590) described and depicted whitecolored flowers as well. The different tomato names, 'aurea' (golden), 'rubrum' (red), 'luteum' (yellow) and 'croceum' (orange-yellow, golden-yellow), also indicate that the fruits came in different colors.

481

Tomatoes underwent a dramatic increase in fruit size during domestication: some modern cultivars produce fruit a thousand times larger than their wild counterparts (Lin et al., 2014). Wild tomato species generally have flowers with five to six sepals, petals and stamens, and bilocular fruits. Through a mutation known as fasciation, flowers will produce up to eight petals and an increased number of locules, which leads to multisegmented, elongated fruits. Humans probably selected fasciated tomatoes for their large fruits, but only a small portion of all modern tomato cultivars is multilocular (Barrero \& Tanksley, 2004). The fact that the first tomato described in Europe was segmented (Matthioli, 1544, Table 2) proves that the early sixteenth- 
490

491

492

493

494

495

496

497

498

499

500

501

502

503

504

505

506

507

508

509

510

511

512

513

514

515

516

517

518

519

520

521

522

523

524

525

526

527

528

529

century tomatoes did not come from wild plants but represented a crop that had reached a fairly advanced stage of domestication (Bai \& Lindhout, 2007).

Table 2 shows that most sixteenth-century specimens lack preserved fruits: juicy tomatoes cannot be easily pressed into botanical vouchers. They are bulky and will not keep their shape when pressed, and due to their moisture, the specimens will quickly start to mold. Petrollini's first tomato specimen had only an immature fruit, but when preparing the tomato specimen in the En Tibi herbarium, he skillfully removed the juicy insides of the tomato and pressed the skin of the fruit to represent its round shape (Fig. 1C). Ratzenberger's fruits seem to have spoiled and have been removed from the specimen (Fig. 1J). Harder found a solution: he pressed a flowering specimen and drew the roots, ripe and golden fruits later on the paper (Fig. 1H).

\section{Genetic origin of the En Tibi tomato}

What was the geographical origin of the early tomatoes that sparked the interest of the Renaissance botanists? The sixteenth-century literature, specimens and illustrations do not answer this question. The Peruvian origin mentioned by Michiel and Anguillara is not specific, and apart from Guilandinus (1572), the other early sources do not discuss any geographical origin. The knowledge on tomatoes circulating in Europe during the sixteenth-century came from plants that were already cultivated in gardens, as is evident from the detailed morphological descriptions on fruit shape and color, characters that were only observable in living plants. The provenance from the obscure New World was not of interest to most sixteenth-century scholars, who tried hard to trace the tomato in the writings of ancient Greek authors. Regarding herbarium specimens, we only know that the Rauwolf tomato was collected somewhere in N. Italy (Stefanaki et al., 2021), while C. Bauhin's tomatoes were possibly cultivated in his garden in Basel.

The question of geographical origin may also be approached by genomic research on the crop's earliest herbarium specimens. Recently, DNA was extracted from a leaf of the tomato specimen in the En Tibi herbarium (c. 1558, Bologna, kept at Naturalis), and its whole genome was sequenced using Illumina TruSeq technology (Michels, 2020) and published online (https://www.ncbi.nlm.nih.gov/bioproject/PRJNA566320; sequencing read archive number SRS5407108). The En Tibi genome was then mapped to the Heinz 1706 reference genome (The Tomato Genome Consortium, 2012), with an average sequencing depth of 2.28 (Michels, 2020). Only 9.9 Mbp were recovered with $\geq 10 \mathrm{x}$ depth, which equated to $1.2 \%$ of the reference genome. This indicated that the specimen's DNA had severely fragmented over the past 475 years. Data on genome assemblies of 114 accessions of wild species and traditional cultivars from Latin America were retrieved from the 360-tomato resequencing project (Lin et al., 2014; https://solgenomics.net/organism/Solanum_ycopersicum/tomato_360) and cropped to span only the $1.2 \%$ of the sequenced En Tibi genome with sufficient coverage. 
530 To identify the En Tibi tomato's nearest neighbors, Michels (2020) performed a network

531 clustering analysis (NeighborNet, Bryant 2003). Dimensionality reduction analyses were carried

532 out on the remaining SNPs to investigate coarse genetic similarity among the accessions. In Fig.

533 3, the lengths of the terminal branches are proportional to the number of autapomorphies,

534 distinctive genetic features that are unique to each taxon. Wild populations are generally more

535 genetically diverse (and thus have higher numbers of autapomorphies) than domesticated ones,

536 because of the founder events of domestication and deliberate inbreeding. The highly diverse,

537 wild Solanum pimpinellifolium accessions (dark green circles) spread out on the left (Fig. 3A).

538 On the right, the En Tibi tomato clustered in the group of domesticated tomatoes ( $S$.

539 lycopersicum) from both Central and South America, with very short branches (Fig. 3B). The

540 graph also shows that some accessions of the cherry tomato (S. lycopersicum var. cerasiforme)

541 are genetically close to the large-fruited domesticated tomato varieties on both parts of the

542 continent. In contrast, other accessions of cherry tomatoes appear to be truly wild, given their

543 long branches.

544

545

546

547

548

549

550

551

552

553

554

555

556

557

558

559

560

561

562

563

564

565

566

567

568

Table 3 shows the genetically close varieties to the En Tibi tomato, and some of the associated data stored for these accessions in the C.M. Rick Tomato Genetics Resource Center (TGRC, https://tgrc.ucdavis.edu) at the University of California at Davis, USA. While the three Mexican accessions are characterized as 'Latin American cultivars' (probably landraces are meant here), the other three accessions are classified in the TGRC database as 'wild'. However, C-61 was collected from a family garden and C-281 in open vegetation along a road in the (once) heavily forested eastern Andean foothills. Very little information from the farmers themselves is stored for the accessions close to the En Tibi tomato. B-249 is the only one with a vernacular name (Zocato, no language indicated), and B-153 was collected on a market but said to grow wild. For C-281, the sentence "Indian women: no word in Quechua" in the database suggests that the collector tried to obtain information from a local person, but communication was not possible. The presumably 'wild state' of some of the accessions close to the En Tibi tomato does not coincide with the molecular data, which show that the sixteenth-century tomato was a fully domesticated crop. Combined with the absence of farmers' knowledge in the database, the information in the TGRC database on the domestication status of these accessions is questionable. Some of the nearest neighbors of the En Tibi tomato that were listed as 'wild' in the germplasm data may have escaped from cultivation. Compared to genuinely wild accessions, the branches of these presumably feralized ones are so short that they are very likely to have passed through domestication processes and/or possible hybridization with cultivated tomatoes.

Michels (2020) also found that the En Tibi tomato specimen was more heterozygous than all recently collected accessions from Mesoamerica sequenced by Lin et al. (2014), which had a narrower genetic background. This means that the sixteenth-century specimen was less inbred or domesticated than its current counterparts in Mexico. However, some South American 
569 domesticated tomatoes had even higher heterozygosity, perhaps due to gene flow between

570 landraces and crop wild relatives (Michels, 2020).

571

\section{Discussion}

573 Recently, the chloroplast DNA of the En Tibi specimen was completely retrieved at high

574 coverage by Kakakiou (2021). Consequently, the En Tibi plastome was mapped to the

575 chloroplast genome of S. lycopersicum (NC_007898) and haplotype networks were constructed

576 using the Median-Joining (MJ) method and the accessions of the 360-tomato resequencing

577 project (Lin et al., 2014) to reveal the nearest relatives and give clues regarding its origin. The En

578 Tibi specimen was placed in the same node as all Mesoamerican individuals, together with some

579 Ecuadorian and Peruvian accessions of S. lycopersicum var. cerasiforme (Kakakiou, 2021).

580

581 The molecular research on the En Tibi tomato does not provide a definite answer to the exact

582 locality of its domestication, and it was impossible to appoint the En Tibi as a direct ancestor of

583 some modern tomato varieties. However, its predecessor likely came from Mesoamerica. The

584 latest study on the origin of domesticated tomatoes (Blanca 2021; Blanca et al. 2021) proposed a

585 domestication model considering that the wild forms of S. lycopersicum var. cerasiforme from

586 Mexico have travelled with indigenous people to South America, probably as a weed among

587 maize grains, where it hybridized with wild individuals of $S$. pimpinellifolium. This hypothesis

588 also considered that as part of the domestication process, people then started to select these

589 hybrids and took them back to Mexico, where they generated S. lycopersicum var. lycopersicum

590 with larger fruits. The Peruvian cherry tomato accessions that were close to the En Tibi tomato

591 were probably also cultivated, and carried some Mesoamerican ancestry that could reflect the

592 domestication model outlined by Blanca et al. (2021).

593

594 As more than $98 \%$ of its genome could not be read, it is impossible to reconstruct complete gene

595 sequences coding for taste or natural resistance to pest and diseases (Michels, 2020), despite

596 anticipation of this earlier (Van Santen 2012, De Boer, 2013). To reconstruct the 'original'

597 flavor, nutritional qualities and adaptations to the (a)biotic environment of sixteenth-century

598 tomatoes, assuming that these tomatoes possessed those traits and that they were lost through

599 intensive breeding for yield in modern cultivars (Klee \& Resende, 2020), research should focus

600 on traditional landraces currently grown by small farmers in Central and South America that

601 most resemble historic varieties.

602

603 The accessions sequenced by Lin et al. (2014) in the 360-tomato project reflect centuries of

604 human migration and trade, which has caused extensive gene flow between tomato varieties. The

605 information was obtained from online genomic data, and germplasm institutes store very little

606 information on exact localities or morphological, nutritional and agronomical qualities of these

607 accessions or on the farmers that grow them. Moreover, this resequencing project did not capture

608 the entire tomato diversity in the Americas. Increased sampling of landraces in the Andes and 
609 Mesoamerica is essential to fully characterize tomato diversity (Knapp \& Peralta, 2016). With

610 decreasing crop diversity and the social, economic and ecological challenges faced by small

611 farmers of indigenous descent to preserve their traditional agricultural practices (Knapp \&

612 Peralta, 2016; Petropoulos, Barros \& Ferreira, 2019), tracing the 'sisters' of the En Tibi tomato

613 back to Mexican or Peruvian smallholders' gardens will be difficult. The landraces that were

614 genetically close to the En Tibi tomato were collected between 36 and 52 years ago: they may

615 have already disappeared from indigenous gardens and survive only as seeds in germplasm

616 institutes.

617

\section{Conclusions}

619 The earliest tomatoes that reached Europe came in a wide variety of colors, shapes and sizes:

620 with both simple and fasciated flowers, round and segmented fruits. The first description of a

621 tomato was published by Matthioli in 1544, while the oldest specimens were collected by

622 Aldrovandi and Petrollini in c. 1551 in the Pisa botanical garden. The earliest illustrations were

623 made in Germany and Flanders in the early 1550s. The names of early tomatoes in contemporary

624 manuscripts suggest both a Mexican and a Peruvian origin. The 'En Tibi' specimen was

625 collected by Petrollini around 1558 and thus is not the oldest extant tomato, although it is the

626 first specimen that shows a mature fruit. Although only 1.2\% of its nuclear DNA was recovered,

627 molecular research on its genome and plastome shows that the En Tibi specimen was a fully

628 domesticated tomato, and genetically close to three Mexican landraces and two Peruvian tomato

629 accessions that most probably also had a Mesoamerican origin.

630

631 Molecular research on the other sixteenth-century tomato specimens may reveal additional

632 patterns of genetic similarity and geographic origin. Clues on the 'historic' taste and pest

633 resistance of the sixteenth-century tomatoes are difficult to find in their degraded DNA, but

634 should rather be sought in those landraces in Central and South America that are genetically

635 close to them. The indigenous farmers growing these traditional varieties should be supported to

636 conserve these heirloom varieties in-situ.

637

638 Sequencing the ancient DNA of the other nine sixteenth-century tomato specimens highlighted in 639 our paper may provide different but equally exciting snapshots of historic genetic variation. This 640 may lead to different, similar-looking landraces in either South- or Mesoamerica. Further 641 digitization, translation and online publication of Aldrovandi's manuscripts, archives of botanical 642 gardens and correspondence between Renaissance naturalists will probably reveal more details 643 on the first New World crops in Europe, their geographic origin and arrival date.

644

\section{Acknowledgements}

646 We would like to thank the staff of libraries and universities who provided us with digital images

647 of specimens, illustrations, rare books and manuscripts: Adriano Soldano, Annalisa Managlia,

648 Martina Caroli and Silvia Tebaldi of the University of Bologna (Aldrovandi herbarium), Gerda 
649 van Uffelen of the Hortus Botanicus Leiden and Izabela Korczyńska of the Jagiellonian library in 650 Krakow (Libri Picturati), Gisela Glaeser of the Universitätsbibliothek der FAU Erlangen651 Nürnberg (Oellinger and Gesner illustrations), Raffaella Alterio and Mario Setter, of the 652 Biblioteca Angelica (Erbario B), Rome, Karien Lahaise, Naturalis library (literature), Jurriaan de 653 Vos, University of Basel (C. Bauhin herbarium), the staff of the Archivio di Stato di Modena 654 (Ducale Estense herbarium), the staff of Biblioteca Marciana, Venice and Alessandro Moro 655 (Michiel's illustrations), Peter Mansfeld, Naturkundemuseum Kassel (Ratzenberger herbarium), 656 Sophie Schrader, Bayerische Staatsbibliothek München (Harder herbarium), and Peter Prokop of 657 the Österreichische Nationalbibliothek, Vienna (Fuchs illustration). DNA extraction was carried 658 out by Barbara Gravendeel (Naturalis) and sequencing was carried out by Elio Schijlen 659 (Wageningen University). We are also grateful to José Blanca who shared his group's latest 660 findings on the history of tomato domestication.

661

662 References

663

664

665

666

667

668

669

670

671

672

673

674

675

676

677

678

679

680

681

682

683

684

685

686

687

688

Anguillara LM. 1561. Semplici, li quali in più parerei a diversi nobili huomini scritti Appaiono. Venice: Vincenzo Valgrisi.

Arber A. 1986. Herbals, their origins and evolution: A chapter in the history of botany, 14701670. Cambridge: Cambridge University Press.

Bai Y, Lindhout P. 2007. Domestication and breeding of tomatoes: What have we gained and what can we gain in the future? Annals of Botany 100(5): 1085-1094. doi: https://doi.org/10.1093/aob/mcm150

Bailey LH. 1886. Notes on tomatoes. East Lansing: Agricultural College of Michigan. Bakker FT, Antonelli A, Clarke JA, Cook JA, Edwards SV, Ericson PG, Faurby S, Ferrand N, Gelang M, Gillespie RG, Irestedt M, Lundin K, Larsson E, Matos-Maraví P, Müller J, Von Proschwitz T, Roderick GK, Schliep A, Wahlberg N, Wiedenhoeft J, Källersjö, M. 2020. The Global Museum: Natural history collections and the future of evolutionary science and public education. PeerJ 8: e8225. Doi: 10.7717/peerj.8225.

Barrero LS, Tanksley SD. 2004. Evaluating the genetic basis of multiple- locule fruit in a broad cross section of tomato cultivars. Theoretical and Applied Genetics 109: 669-679. Doi: 10.1007/s00122-004-1676-y.

Bauhin C. 1596. Phytopinax, seu, Enumeratio plantarum ab herbariis nostro ...... plantarum viuis iconibus. Basel: Sebastianum Henricpetri. Available at https://www.biodiversitylibrary.org/item/30648\#page/346/mode/1up

Bauhin C. 1598. Petri Andrea Matthioli opera quae extant omnia. Frankfurt: Nikolaus Basse. Available at https://play.google.com/books/reader?id=W99s3SJjLaAC\&hl=en_GB\&pg=GBS.PA760

Bauhin J, Cherler JH. 1651. Historia plantarum universalis, nova, et absolutissima, cum consensu et dissensu circa eas. 3rd vol. Yverdon: Dominicus Chabraeus.

Baumann B, Baumann H, Baumann-Schleihauf S. 2001. Die Kräuterbuch-Handschrift des Leonhart Fuchs. Stuttgart: Ulmer. 
689 Besler B. 1613 [2008]. Hortus Eystetensis. Annotated edition, Schirmer/Mosel: Taschen.

690

691

692

693

694

695

696

697

698

699

700

701

702

703

704

705

706

707

708

709

710

711

712

713

714

715

716

717

718

719

720

721

722

723

724

725

726

727

728

Blanca J. 2021. Tomato origin and domestication. Youtube Presentation, available on https://www.youtube.com/watch?v=yUj4Tv7fkHQ (last accessed November 2021).

Blanca J, Sanchez-Matarredona D, Ziarsolo P, J Montero-Pau, Van der Knaap E, Díez MJ, Cañizares J. 2021. Haplotype analyses reveal novel insights into tomato history and domestication including long-distance migrations and latitudinal adaptations. BioRxiv preprint. Available at: doi: $\underline{\text { https://doi.org/10.1101/2021.06.18.448912 }}$

Blanca J, Montero-Pau J, Sauvage C, Bauchet G, Illa E, Díez MJ, Francis D, Causse M, Van der Knaap E, Cañizares J. 2015. Genomic variation in tomato, from wild ancestors to contemporary breeding accessions. BMC genomics 16(1): 1-19.

Bryant D. 2003. Neighbor-Net: an agglomerative method for the construction of phylogenetic networks. Molecular Biology and Evolution 21(2): 255-65. Doi: 10.1093/molbev/msh018.

Camerarius J. 1586. De Plantis Epitome Utilissima. Frankfurt am Main: Peter Fischer, Heinrich Dack. Available at https://archive.org/details/BIUSante_07755x01

Camerarius, J. 1590. Kreutterbuch Desz Hochgelehrten vnnd weitberühmten Herrn D. Petri Andreae Matthioli: Jetzt widerumb mit viel schönen neuwen Figuren.... Frankfurt am Main: Peter Fischer, Heinrich Dack. Available at: http://digital.ub.uniduesseldorf.de/vester/content/titleinfo/4025416

Camus J, Penzig OAJ. 1885. Illustrazione del ducale Erbario Estense conservato nel R. Archivio di Stato in Modena. Modena: GT Vincenzi e nipoti.

Caruel T. 1858. Illustratio in hortum siccum Andreae Caesalpini. Florence: Le Monnier.

Cesalpino A. 1583. De plantis Libri XVI. Florence: Georgi Marescotti. Available at https://www.biodiversitylibrary.org/bibliography/60929\#/summary

Chiovenda E. 1909. Francesco Petrollini, botanico del secolo XVI. Annali di Botanica 7: 339_ 447.

Chiovenda E. 1927. Un antichissimo erbario anonimo del Museo Botanico di Firenze. Annali di Botanica 17: 119-139.

Christenhusz MJ. 2004. The hortus siccus (1566) of Petrus Cadé: a description of the oldest known collection of dried plants made in the Low Countries. Archives of Natural History 31(1): 30-43.

Daunay MC, Laterrot H, Janick J. 2006. Iconography of the Solanaceae from Antiquity to the XVIIth century: A rich source of information. Acta Horticulturae 745: 59-88.

De Boer M. 2013. De smaak van een eeuwenoude tomaat. Naturalis Biodiversity Center: het maatschappelijk belang van biodiversiteit. NRC Handelsblad Supplement 7 September 2013: 4.

De Candolle A. 1885. Origin of cultivated plants, $1^{\text {st }}$ American edition. New York: D. Appleton and $\mathrm{Co}$

De Lobel M, Pena P. 1571. Stirpium Adversaria Nova. London: Thomas Purfoot. Available at https://bibdigital.rjb.csic.es/viewer/13064/?offset=\#page $=131 \&$ viewer $=$ picture\&o=search\&n= $\underline{0 \& \mathrm{q}=\text { amoris }}$

Peer] reviewing PDF | (2021:04:59968:2:0:NEW 25 Nov 2021) 
729

730

731

732

733

734

735

736

737

738

739

740

741

742

743

744

745

746

747

748

749

750

751

752

753

754

755

756

757

758

759

760

761

762

763

764

765

766

767

768

De Lobel M. 1576. Plantarum seu stirpium historia. Antwerp: Christopher Plantin. Avaialble at https://bibdigital.rjb.csic.es/viewer/13070/?offset=\#page $=1 \&$ viewer $=$ picture $\& 0=0 c r \& n=0 \& q=$ $\underline{\text { amoris }}$

De Sahagún B. c. 1577. Historia general de las cosas de Nueva España por el fray Bernardino de Sahagún: el Códice Florentino. Libro X: del pueblo, sus virtudes y vicios, y otras naciones. Florence: Mss. Biblioteca Medicea Laurenziana, Florence. Available at http://www.wdl.org/es/item/10621/\#collection=florentine-codex.

De Toni GB. 1907. Spigolature Aldrovandiane. VI. Le piante dell'antico Orto Botanico di Pisa ai tempi di Luca Ghini. Annali di Botanica Volume V (3): 421-440.

De Toni GB. 1910. Spigolature Aldrovandiane IX. Nuovi documenti intorno Francesco Petrollini, prima guida di Ulisse Aldrovandi nello studio delle piante. Atti del Reale Istituto Veneto di Scienze, Lettere ed Arti 69: 815-825.

De Toni E. 1940. Michiel, Pietro Antonio. I cinque libri di piante. Codice Marciano, 1551-1575. Venice: Officine Grafiche Carlo Ferrari.

Dioscorides P. c. 60 AD. De Materia Medica.

Dodoens R. 1553. De stirpium historia commentariorum imagines ad vivum expressae... Antwerp: Ioannis Loei. Available at https://www.biodiversitylibrary.org/page/6726576\#page/2/mode/1up

Dodoens R. 1583. Stirpium Historiae Pemptades Sex sive Libri XXX. Antwerp: Christopher Plantin. Available at $\underline{\text { https://bibdigital.rjb.csic.es/viewer/10942/?offset=\#page }=1 \& \text { viewer }=\text { picture } \& \mathrm{o}=\mathrm{search} \& \mathrm{n}=0}$ $\underline{\& q}=$

Egmond F. 2010. The world of Carolus Clusius: Natural history in the making, 1550-1610. London: Pickering \& Chatto.

Egmond F. 2016. The garden of nature: visualizing botanical research in northern and southern Europe in the 16th century. In: Ferdinand J, ed. From art to science: Experiencing nature in the European garden 1500-1700. Treviso: ZeL Edizioni, 18-33.

Egmond F. 2018. European exchanges and communities. In: Curry A, Jardine N, Secord JA, Spary EC, eds. Worlds of Natural History. Cambridge: Cambridge University Press, 78-93.

Findlen P. 1994. Possessing nature: Museums, collecting, and scientific culture in Early Modern Italy. Berkeley: University of California Press.

Findlen P. 2017. The death of a naturalist: Knowledge and community in late Renaissance Italy. In: Manning G, Klestinec C. Professors, Physicians and Practices in the History of Medicine. Cham: Springer, 127-168.

Frati L, Ghigi A, Sorbelli A. 1907. Catalogo dei manoscritti di Ulisse Aldrovandi. Bologna: Nicola Zanichelli, 127-168

Fuchs L. 1542. De Historia Stirpium Commentarii insignes. Basel: Officina Isingriniana. Available at https://bibdigital.rjb.csic.es/viewer/13865/?offset=\#page=77\&viewer=picture\&o=bookmark\& $\underline{\mathrm{n}=0 \& \mathrm{q}=}$ 
769 Gentilcore D. 2010. Pomodoro! A history of the tomato in Italy. New York: Columbia University 770 Press.

771 Gesner C. 1561. In hoc volumine continentur ....De hortus Germaniae. Argentorati: Iosias

772 Rihelius. Available at https://www.biodiversitylibrary.org/item/33559\#page/1/mode/1up

773 Gray A, Trumbull JH. 1883. Review of De Candolle's origin of cultivated plants; with

774

775

776

777

778

779

780

781

782

783

784

785

786

787

788

789

790

791

792

793

794

795

796

797

798

799

800

801

802

803

804

805

806

807 annotations upon certain American species. American Journal of Science 3(148): 128-138.

Guilandinus M. 1572. Papyrus, hoc est commentarius in tria C. Plinij maioris de papyro capita. Venice: Antonium Ulmum. Available at https://play.google.com/store/books/details?id=Lq4vsSs34OkC\&rdid=book$\underline{\mathrm{Lq} 4 \mathrm{vs} S \mathrm{~s} 34 \mathrm{OkC} \& \mathrm{rdot}=1}$

Houchin R. 2010. Praten over tomaten: Introductie van tomaat (Solanum lycopersicum L.) in de Lage Landen. In: Bakels CC, Fennema K, Out W, Vermeeren C., eds. Van planten en slakken. Leiden, Sidestone Press, 81-102.

Jenkins JA. 1948. The origin of the cultivated tomato. Economic Botany 2(4): 379-392.

Kakakiou V. 2021. Plastid genome analysis of the En Tibi specimen shows Mesoamerican origin. Leiden: MSc thesis, Leiden University. Available at:

https://www.researchgate.net/publication/355163967_Plastid_genome_analysis_of_the_En_T ibi_specimen_shows_Mesoamerican_origin

Katz E. 2009. Chili pepper, from Mexico to Europe: Food, imaginary and cultural identity. In: Medina FX, Ávila R, De Garine, I. Food, Imaginaries and Cultural Frontiers: Essays in honour of Helen Macbeth. Guadalajara: Universidad de Guadalajara, 213-232.

Kessler HF. 1870. Das älteste und erste Herbarium Deutschlands, im Jahre 1592 von Dr. Caspar Ratzenberger angelegt: gegenwärtig noch im Königlichen Museum zu Cassel befindlich. Kassel: Freyschmidt. Available at http://mdz-nbn-resolving.de/urn:nbn:de:bvb:12bsb11018583-2

Klee HJ, Resende Jr. MF. 2020. Plant domestication: Reconstructing the route to modern tomatoes. Current Biology 30(8): R359-R361.

Knapp S, Peralta IE. 2016. The tomato (Solanum lycopersicum L., Solanaceae) and its botanical relatives. London: Natural History Museum.

Koning J, van Uffelen G, Zemanek A, Zemanek B. 2008. Drawn after nature: the complete botanical watercolours of the 16th-century Libri Picturati. Leiden: Brill.

Larranaga N, Van Zonneveld M, Hormaza JI. 2021. Holocene land and sea-trade routes explain complex patterns of pre-Columbian crop dispersion. New Phytologist 229(3): 1768-1781.

Lin T, Zhu G, Zhang J, Xu X, Yu Q, Zheng Z, Zhang Z, Lun Y, Li S, Wang X, Huang Z, Li J, Zhang C, Wang T, Zhang Y, Wang A, Zhang Y, Lin K, Li K, Xiong G, Xue Y, Mazzucato A, Causse M, Fei Z, Giovannoni JJ, Chetelat RT, Zamir D, Städler T, Li J, Ye Z, Du Y, Huang S. 2014. Genomic analyses provide insights into the history of tomato breeding. Nature Genetics 46(11): $1220-1226$.

808 Long J. 1995. De tomates y jitomates en el siglo XVI. Estudios de Cultura Náhuatl 25: 239-252. 
809 López-Terrada M. n.d. The history of the arrival of the tomato in Europe: an initial overview.

$810 \quad$ Traditom. Available at

811 http://traditom.eu/fileadmin/traditom/downloads/TRADITOM History of the arrival of the

812 tomato in Europe.pdf

813 Luztze E, Retzlaff H. 1949. Herbarium des Georg Oellinger anno 1553 zu Nürnberg. Salzburg:

814 Akademischer Gemeinschaftsverlag.

815 Matthioli PA. 1544. Di Pedacio Dioscoride Anazarbeo libri cinque della historia, et materia

816 medicinale trodotti in lingua volgare Italiana. Venice: Nicolo de Bascarini.

817 Matthioli PA. 1548. Commentarii, in libros sex Pedacii Dioscorides Anarzabei, de materia

818 medica.,Venice: Valgrisius. Available at

819 https://classic.europeana.eu/portal/nl/record/92004/NKCR NKCR 5 H 000058 45VM

$820 \quad 8 \mathrm{U} 7 \mathrm{cs.html}$ ?utm source=new-website\&utm medium=button

821 Matthioli PA. 1554. Commentarii in libros sex Pedacii Dioscoridis Anazarbei, de medica

822 materia. Venice: Valgrisius. Available at

823 https://books.google.nl/books? $\mathrm{id}=$ HEhdAAAAcAAJ\&printsec $=$ frontcover\&cad=0\#v=onepag

$824 \quad$ e\&q\&f=true

825 McCue GA. 1952. The history of the use of the tomato: an annotated bibliography. Annals of the

826 Missouri Botanical Garden 39(4): 289-348.

827 Metro-Roland MM. 2013. Goulash nationalism: the culinary identity of a nation. Journal of

$828 \quad$ Heritage Tourism 8(2-3): 172-181.

829 Meyer FG, Trueblood EE, Heller JL. 1999. The great herbal of Leonhart Fuchs: de historia

830 stirpium commentarii insignes, 1542. Stanford: Stanford University Press.

831 Michels E. 2019. The phylogeography and functional genomics of the En Tibi tomato specimen.

832 Leiden: MSc thesis, Leiden University. Available at:

833 https://www.researchgate.net/publication/355062128 The phylogeography_and_functional_g

834 enomics of the En Tibi tomato specimen.

835 Miller P. 1754. The gardener's dictionary, abridged 4th ed. London: John and James Rivington.

836 Minelli A. 2010. Michiel, Pietro Antonio. Dizionario Biografico degli Italiani, Volume 74.

837 Available at https://www.treccani.it/enciclopedia/pietro-antonio-michiel_(Dizionario-

838 Biografico).

839 Palmer R. 1985. Medical botany in northern Italy in the Renaissance. Journal of the Royal

$840 \quad$ Society of Medicine 78(2): 149-157.

841 Pardo Tomás J, López Terrada ML. 1993. Las primeras noticias sobre plantas Americanas en

842 las relaciones de viajes y crónicas de Indias (1493-1553). Cuadernos Valencianos de Historia

843 de la Medicina y de la Ciencia XL, Serie A (Monografías). Valencia: Universitat de Valencia.

844 Penzig OAJ. 1905. Illustrazione degli erbarii di Gherardo Cibo. In: Penzig OAJ, ed.

845 Contribuzioni alla storia della botanica. Milan: U. Hoepli, 1-237.

846 Peralta IE, Spooner DM. 2007. History, origin and cultivation of tomato (Solanaceae). In:

847 Razdan MK, Mattoo AK. Genetic improvement of Solanaceous crops, Vol.1: Tomato. Boca

848 Raton: Science Publishers, 1-27. 
849 Peralta IE, Spooner DM, Knapp S. 2008. Taxonomy of wild tomatoes and their relatives

850

851

852

853

854

855

856

857

858

859

860

861

862

863

864

865

866

867

868

869

870

871

872

873

874

875

876

877

878

879

880

881

882

883

884

885

886

887

(Solanum sect. Lycopersicoides, sect. Juglandifolia, sect. Lycopersicon; Solanaceae).

Systematic Botany Monographs 84. Laramie: American Society of Plant Taxonomists.

Petropoulos SA, Barros L, Ferreira ICFR. 2019. Rediscovering local landraces: Shaping

horticulture for the future. Frontiers in Plant Science 10: 126. Doi: 10.3389/fpls.2019.00126.

PROTA. 2015. Bibliographic details for Solanum aethiopicum. Wageningen: Plant Resources of

Tropical Africa. Available at https://uses.plantnet-

project.org/en/Solanum aethiopicum (PROTA)

Rotelli F. 2018. Exotic plants in Italian pharmacopoeia (16th-17th centuries). Medicina nei Secoli 30(3): 827-880.

Smith AF. 1994. The tomato in America: Early history, culture, and cookery. Columbia: University of South Carolina Press.

Soldano A. 2000. La provenienza delle raccolte dell'erbario di Ulisse Aldrovandi, Volumi I e II. Atti dell' Istituto Veneto di Scienze, Lettere ed Arti, Classe de Scienze fisiche, Matematiche e Naturali 158: 1-246.

Speta F, Grims F. 1980. Hieronymus Harder und sein „Linzer” Herbarium aus den Jahre 1599. Kataloge des Ö̈. Landesmuseums 105, zugleich Linzer Biologische Beiträge 12: 307-330

Staats M, Erkens RH, Van de Vossenberg B, Wieringa JJ, Kraaijeveld K, Stielow B, Geml J, Richardson JE, Bakker FT. 2013. Genomic treasure troves: complete genome sequencing of herbarium and insect museum specimens. PLoS ONE 8(7): e69189.

Stefanaki A, Thijsse G, van Uffelen G, Eurlings M, van Andel TR. 2018. The En Tibi herbarium, a $16^{\text {th }}$ century Italian treasure. Botanical Journal of the Linnaean Society 187: 397-427.

Stefanaki A, Porck H, Grimaldi IM, Thurn N, Pugliano V, Kardinaal A, Salemink J, Thijsse G, Chavannes-Mazel C, Kwakkel E, Van Andel TR. 2019. Breaking the silence of the 500-yearold smiling garden of everlasting flowers: The En Tibi book herbarium. PLoS ONE 14(6): e0217779.

Stefanaki A, Walter T, Porck H, Bertin A, Van Andel TR. 2021. The early book herbaria of Leonhard Rauwolf (S. France and N. Italy, 1560-1563): new light on a plant collection from the 'golden age of botany'. Rendiconti Lincei Scienze Fisiche e Naturali 32: 449-461.

Sturtevant EL. 1919. Notes on edible plants. Report of the New York Experiment Station of the year 1919. Albany: J.B. Lyon Company. Available at https://uses.plantnetproject.org/en/Lycopersicum (Sturtevant, 1919)

The Tomato Genome Consortium. 2012. The tomato genome sequence provides insights into fleshy fruit evolution. Nature 485(7400): 635-41. Doi: 10.1038/nature11119.

Thijsse G. 2012. Gedroogde schatten. In: van Gelder E, ed. Bloeiende kennis: Groene ontdekkingen in de Gouden Eeuw. Hilversum: Uitgeverij Verloren, 36-54.

Thijsse G. 2016. 'Tussen pampier geleyt': Ontstaan, verspreiding en gebruik van de vroegste herbaria. In: IJpelaar L, Chavannes-Mazel CA, eds. De groene Middeleeuwen. Duizend jaar gebruik van planten (600-1600). Eindhoven: Lecturis BV, 64-93.

Peer) reviewing PDF | (2021:04:59968:2:0:NEW 25 Nov 2021) 
888 Toresella S. 1992. Le prime piante americane negli erbari del Cinquecento. Le Scienze 281: 4688957.

890 Ubriszy Savoia A. 1993. Le piante americane nell'Erbario di Ulisse Aldrovandi. Webbia 48:

$891 \quad 579-598$.

892 Van Santen H. 2012 De alleroudste tomaat ligt in Leiden. NRC Handelsblad 17 July 2012: 16.

893 Van Andel TR, Meyer RS, Aflitos SA, Carney JA, Veltman MA, Copetti D, Flowers JM, 894 Havinga RM, Maat M, Purugganan MD, Wing RA, Schranz ME. 2016. Tracing ancestor rice 895 of Suriname Maroons back to its African origin. Nature Plants 2(10): 1-5. Doi:

$896 \quad 10.1038 /$ nplants.2016.149

897 Van Andel TR. 2017. Open the treasure room and decolonize the museum. Inaugural lecture for 898 the Clusius chair in History of Botany and Gardens. Leiden: Leiden University.

899 Vandewiele LJ. 1993. Wat groeide er in de tuin van Pieter van Coudenberghe? In: De Nave F, 900 Imhof D, eds. De Botanica in de Zuidelijke Nederlanden (einde 15de eeuw-ca. 1650)

901 Antwerp: Museum Plantin-Moretus and Stedelijk Prentenkabinet, 23-31.

902

903 
904

905

906

907

908

909

910

911

912

913

914

915

916

917

918

919

920

921

922

923

924

925

926

927

928

929

930

931

932

933

934

935

936

937

938

939

940

941

942

943

944

945

946

947

948

949

950

Figure 1: All extant specimens of tomatoes in sixteenth-century herbaria, in chronological order. (A) Ulisse Aldrovandi (c. 1551), Vol 1, p. 368. The pair of leaves at the bottom of the page belong to a Citrullus. Photo credit: University of Bologna. (B) Francesco Petrollini (pre1553) Photo credit: Biblioteca Angelica, Rome, c.49r, Erbario Cibo B, vol. 3. (C) Francesco Petrollini (c. 1558), L.2111092, 'En Tibi tomato'. Photo credit: Naturalis, Leiden. (D) Leonhard Rauwolf (1563), Photo credit: Naturalis, Leiden. (E) Caspar Bauhin (1577-1624) B15-075.2A. Photo credit: Herbaria Basel, University of Basel. (F) Bauhin B15-075.2B_1. Photo credit: Herbaria Basel, University of Basel. (G) Bauhin B15-075.2B_2. Photo credit: Herbaria Basel, University of Basel. (H) Hieronymous Harder (1576-1594), Photo credit: Bayerische Staatsbibliothek München, Cod.icon. 3, fol. 140v. (I) Ducale Estense herbarium (1570-1580), Photo credit: Archivio di Stato di Modena. (J) Caspar Ratzenberger (1592), Photo credit: Naturkundemuseum Kassel. Written permission to publish these images is provided in Supplementary Figure 3.

Figure 2: Published and unpublished $16^{\text {th }}$ century tomato illustrations, in chronological order. (A) Dodoens (1553), (B) Dodoens (1554), (C) Gesner (1553), image credit: Universitätsbibliothek der FAU Erlangen-Nürnberg, MS 2386, 37v, (D) Gesner manuscript (1553), image credit: Universitätsbibliothek der FAU Erlangen-Nürnberg, MS 2386, 42r, (E) Fuchs (1549-1556-1561), image credit: Österreichische Nationalbibliothek, (F) Domenico Dalle Greche / Michiel (1550-1576), image credit: Biblioteca Marciana, (G) Oellinger manuscript (1553: 541), image credit: Universitätsbibliothek der FAU Erlangen-Nürnberg, MS 2362, 541, (H) Oellinger (1553: 543), image credit: Universitätsbibliothek der FAU Erlangen-Nürnberg, MS 2362, 543, (I) Oellinger (1553: 545), image credit: Universitätsbibliothek der FAU ErlangenNürnberg, MS 2362, 545, (J) Libri Picturati (1565-1569) A f(olio) 81r, image credit: Jagiellonian library, (K) Libri Picturati A 28 f(olio) 81v, image credit: Jagiellonian library, (L) De Lobel (1572), (M) Camerarius (1586: 821), (N) Camerarius (1590: 378), (O) Bauhin (1598). Written permission to publish these images is provided in Supplementary Figure 3.

Figure 3: Results of the Neighbor Net clustering analysis, showing the genetic similarity of the wild relatives and the domesticated tomato specimens analyzed by Michel (2020). (A) Wild individuals of $S$. pimpinellifolium and S. lycopersicum L. var. cerasiforme from Peru (green circles) and Ecuador (bright green circles) show a high genetic diversity (left of the figure), while a dense cluster of domesticated, genetically less diverse tomatoes is visible on the right, which includes the En Tibi specimen. (B) Enlargement of the cluster with domesticated tomatoes from Figure 3A, showing the nearest neighbors of the En Tibi tomato (dark gray circle), indicated with a red arrow. All distances expressed in Kimura 2-parameter substitutional distance; parsimonyuninformative SNPs excluded. Image credit: Ewout Michels and Rutger Vos.

Peer] reviewing PDF | (2021:04:59968:2:0:NEW 25 Nov 2021) 
951

952

953

954

955

956

957

958

959

960

961

962

963

964
Supplementary Figure 1: Drawing of Solanum aethiopicum in the manuscript of Pietro Antonio Michiel (1510-1576). Artist unknown, manuscript: I cinque libri di piante. Codice Marciano, 1551-1575. Image credit: Biblioteca Marciana, Venice.

Supplementary Figure 2: Specimen of Solanum aethiopicum, collected by Caspar Bauhin between 1577 and 1624. Image credit: Herbaria Basel, University of Basel.

Supplementary Figure 3: Written permission of the various herbaria and libraries to publish the images of the specimens and illustrations. 


\section{Table $\mathbf{1}$ (on next page)}

Table 1

Sixteenth-century descriptions, specimens and illustrations of the tomato, ordered by author and chronologically. 
1 Table 1: Sixteenth-century descriptions, specimens and illustrations of the tomato, ordered by author and chronologically.

\begin{tabular}{|c|c|c|c|}
\hline $\begin{array}{l}\text { Author (birth-death year) } \\
\text { Title of source }\end{array}$ & $\begin{array}{l}\text { Year of publication(s) } \\
\text { with online links }\end{array}$ & Representation & Names \\
\hline $\begin{array}{l}\text { Pietro Andrea Matthioli (1501-1578) } \\
\text { Commentaries on Dioscorides }\end{array}$ & $\begin{array}{l}\begin{array}{l}1544, \underline{1548} \\
1557-1560, \\
1568\end{array} \\
1562, \frac{1549}{1565},\end{array}$ & Text & $\begin{array}{l}\text { 'another species' [of eggplant] (1544, } \\
\text { 1548); pomi d'oro, mala aurea ( } 1554 \\
\text { onwards) }\end{array}$ \\
\hline $\begin{array}{l}\text { Anonymous } \\
\text { Pisa garden catalogue }\end{array}$ & $\begin{array}{l}\text { 1545-1548? } \\
\text { De Toni }(1907: 439) \\
\end{array}$ & Text & $\begin{array}{l}\text { Thumatulum pomum vulgo dictum rubrum } \\
\text { et luteum }\end{array}$ \\
\hline $\begin{array}{l}\text { Vincenzo Ferrini (Pisa) to Pier } \\
\text { Francesco Riccio (Florence) Letter } \\
\text { about showing tomatoes to Cosimo I }\end{array}$ & $\begin{array}{l}31 \text { October } 1548 \\
\text { López-Terrada (n.d.) }\end{array}$ & Text & pomidoro \\
\hline $\begin{array}{l}\text { Ulisse Aldrovandi (1522-1605) } \\
\text { Herbarium } \\
\text { Bologna public garden plant } \\
\text { catalogue }\end{array}$ & $\begin{array}{l}\text { 1551, herbarium vol. } 1 \text {, } \\
\text { fol. } 368 \\
1568-1582\end{array}$ & $\begin{array}{l}\text { Herbarium } \\
\text { specimen }\end{array}$ & $\begin{array}{l}\text { Pomum amoris. Mali insani species. } \\
\text { Tembal quibusd. } \\
\text { Tumatl. seu Pomum amoris quibusdam }\end{array}$ \\
\hline $\begin{array}{l}\text { Rembert Dodoens (c. 1517-1585) } \\
\text { De stirpium historia... } \\
\text { Cruydeboeck }\end{array}$ & $\begin{array}{l}\text { 1553: } 428 \\
\text { 1554: Part III, chapter 82: } \\
471\end{array}$ & $\begin{array}{l}\text { Uncolored } \\
\text { woodcut, text } \\
\text { Colored } \\
\text { woodcut, text }\end{array}$ & $\begin{array}{l}\text { pomum amoris, pomum aureum, Goldt } \\
\text { apffel, guldt appel, pome d'amours } \\
\text { poma amoris, gulden appelen }\end{array}$ \\
\hline $\begin{array}{l}\text { Leonhard Fuchs (1501-1566). } \\
\text { Manuscript, Vienna Codex 11, 122, } \\
\text { p. } 159 \text { (text), } 161 \text { (drawing) }\end{array}$ & $\begin{array}{l}\text { 1549-1556 (-1561) } \\
\text { Partly published (Meyer, } \\
\text { Trueblood \& Heller, 1999; } \\
\text { Baumann, Baumann \& } \\
\text { Baumann-Schleihauf, } \\
\text { 2001). }\end{array}$ & $\begin{array}{l}\text { Text, watercolor } \\
\text { drawing }\end{array}$ & $\begin{array}{l}\text { malus aurea, pomum luteum/rubrum/ } \\
\text { croceum, goldt Apffelkraut, pomme } \\
\text { d'amour }\end{array}$ \\
\hline $\begin{array}{l}\text { Georg Oellinger (1487-1557) } \\
\text { Magnarum Medicinae partium } \\
\text { herbariae .... (manuscript). }\end{array}$ & $\begin{array}{l}\text { c. } 1553, \text { f. } 541,543,545 \\
\text { Partly published by Lutze } \\
\text { \& Retzlaff }(1949)\end{array}$ & $\begin{array}{l}\text { Watercolor } \\
\text { drawings }\end{array}$ & $\begin{array}{l}\text { Mala aurea seu Poma amoris; Poma amoris } \\
\text { maiora Lutea ; }\end{array}$ \\
\hline $\begin{array}{l}\text { Conrad Gesner (1516-1565) } \\
\text { Historia plantarum (manuscript) }\end{array}$ & $\begin{array}{l}\frac{1553}{\text { p. } 37} \text { ( } 22 \text { Serso, p. p. } 42 \text { recto } \\
\end{array}$ & $\begin{array}{l}\text { Watercolor } \\
\text { drawings }\end{array}$ & $\begin{array}{l}\text { Pomo amoris vel aurea, Goldöpfel, pomi } \\
\text { d'oro }\end{array}$ \\
\hline
\end{tabular}




\begin{tabular}{|c|c|c|c|}
\hline $\begin{array}{l}\text { Pietro Antonio Michiel (1510-1576), } \\
\text { I Cinque Libri di Piante, vol. } 3 \\
\text { (Libro Rosso 1: nr. } 46 \text { (illustration } \\
\text { possibly by Domenico Dalle Greche) }\end{array}$ & $\begin{array}{l}1550-1576 \\
\text { Partly published by } \\
\text { DeToni (1940) }\end{array}$ & $\begin{array}{l}\text { Text, watercolor } \\
\text { drawing }\end{array}$ & $\begin{array}{l}\text { Licopersicon Galeni, pomodoro da volgari, } \\
\text { melongiana da latini, Poma amoris; Poma } \\
\text { del Peru. } \\
\text { 'If I should eat of this fruit, cut in slices in } \\
\text { a pan with butter and oil, it would be } \\
\text { injurious and harmful to me' (McCue, } \\
\text { 1952) }\end{array}$ \\
\hline $\begin{array}{l}\text { Francesco Petrollini } \\
\text { Erbario B: Vol. 3, nr.722 }\end{array}$ & before 1553 & $\begin{array}{l}\text { Herbarium } \\
\text { specimen, } \\
\text { text (in index) }\end{array}$ & $\begin{array}{l}\text { Malus insana. Mandragorae species. Poma } \\
\text { amoris }\end{array}$ \\
\hline $\begin{array}{l}\text { Francesco Petrollini En Tibi } \\
\text { herbarium }\end{array}$ & c. $1558:$ Nr. 294 & $\begin{array}{l}\text { Herbarium } \\
\text { specimen }\end{array}$ & Puma Amoris \\
\hline $\begin{array}{l}\text { Anguillara (Luigi Squilerno, } 1512- \\
\text { 1570) } \\
\text { Semplici.... }\end{array}$ & $\begin{array}{l}\frac{1561: 217}{\text { written between } 1549-} \\
1560\end{array}$ & Text & $\begin{array}{l}\text { Lycopersico di Galeni } \\
\text { Pomi d'oro, Pomi del Perù }\end{array}$ \\
\hline $\begin{array}{l}\text { Leonhard Rauwolf (1535-1596), } \\
\text { herbarium }\end{array}$ & 1563 & $\begin{array}{l}\text { Herbarium } \\
\text { specimen }\end{array}$ & Poma aurea \\
\hline $\begin{array}{l}\text { Ducale Estense (anonymous, } \\
\text { herbarium) }\end{array}$ & 1570-1598: nr. 142 & $\begin{array}{l}\text { Herbarium } \\
\text { specimen }\end{array}$ & Pomi di Ettiopia ouer pomi d'oro \\
\hline $\begin{array}{l}\text { Mathias De Lobel (Lobelius, 1538- } \\
\text { 1616) } \\
\text { Stirpium Adversaria Nova } \\
\text { Plantarum seu stirpium historia } \\
\text { Kruydtboeck }\end{array}$ & $\begin{array}{l}\frac{1571: \text { p. } 108}{1576: \text { p. } 108} \\
\underline{1581: 331-332}\end{array}$ & $\begin{array}{l}\text { Text } \\
\text { Text } \\
\text { Text, uncolored } \\
\text { woodcut }\end{array}$ & $\begin{array}{l}\text { Poma amoris, Pomum aureum, } \\
\text { Lycopersiumc quorumdam, an Glaucium } \\
\text { Dioscoridis?, Golt opffel, Gulden appelen, } \\
\text { Pommes dorées, Gold apel. } \\
\text { Memita of the Arabs?, Pommes d'orées, } \\
\text { Gold appel }\end{array}$ \\
\hline $\begin{array}{l}\text { Melchior Wieland (Guilandinus, } \\
\text { 1520-1589), Papyrus.... (1572) }\end{array}$ & 1572: $90-91$ & Text & $\begin{array}{l}\text { Americanorum tumatle } \\
\text { Tumatle ex Themistithan }\end{array}$ \\
\hline Hieronymous Harder (1523-1607). & $\underline{1576-1594}$ & $\begin{array}{l}\text { Herbarium } \\
\text { specimen, } \\
\text { drawing }\end{array}$ & $\begin{array}{l}\text { Solanum marinum alii Poma amoris, } \\
\text { Portugalischer nachtschatt }\end{array}$ \\
\hline $\begin{array}{l}\text { Andrea Cesalpino (1519-1603) } \\
\text { De plantis Libri XVI }\end{array}$ & 1583, lib. IV: 211 & Text & $\begin{array}{l}\text { Mala insana rotundiora, specie Mali Appii, } \\
\text { specie Malii rosei }\end{array}$ \\
\hline
\end{tabular}




\begin{tabular}{|c|c|c|c|}
\hline Libri Picturati (1565-1569?) & $\mathrm{A} 28.080, \mathrm{~A} 28.080 \mathrm{v}$ & Two drawings & Pomme d'amour, pomum amoris, \\
\hline $\begin{array}{l}\text { Joachim Camerarius the Younger } \\
\text { (1534-1598) edited version of } \\
\text { Matthioli’s Commentaries }\end{array}$ & $\begin{array}{l}\text { 1586: } 821 \\
\text { 1590: } 378-379 \\
\end{array}$ & $\begin{array}{l}\text { Uncolored } \\
\text { woodcut } \\
\text { Colored } \\
\text { woodcut }\end{array}$ & $\begin{array}{l}\text { Poma amoris } \\
\text { Goldöpffel, Poma aurea, Amoris poma, } \\
\text { Lycopersico, pomme d'amours, pomi } \\
\text { d'oro }\end{array}$ \\
\hline $\begin{array}{l}\text { Caspar Ratzenberger }(1533-1603) \\
\text { Herbarium Vol. 3: 490-PICT0240 }\end{array}$ & $1556-1592$ & $\begin{array}{l}\text { Herbarium } \\
\text { specimen }\end{array}$ & $\begin{array}{l}\text { Pomidoria, poma aurea, Lieboepffel, } \\
\text { Goldoepffel }\end{array}$ \\
\hline $\begin{array}{l}\text { Caspar Bauhin (1560-1624) } \\
\text { Phytopinax }\end{array}$ & 1596: p. 302-303 & Text & $\begin{array}{l}\text { Solanum pomiferum fructu rotundo, } \\
\text { striato, molli. Poma amoris \& Pomum } \\
\text { aureum Dodon. }\end{array}$ \\
\hline $\begin{array}{l}\text { Caspar Bauhin, edited version of } \\
\text { Matthioli's Commentaries }\end{array}$ & 1598: 761 & $\begin{array}{l}\text { Text, uncolored } \\
\text { woodcut }\end{array}$ & $\begin{array}{l}\text { Citing many names used by others and } \\
\text { Poma Peruuiana Anguil[lara] }\end{array}$ \\
\hline $\begin{array}{l}\text { Caspar Bauhin } \\
(1560-1624)\end{array}$ & $\underline{1577-1624}$ & $\begin{array}{l}\text { Herbarium } \\
\text { specimen }+ \\
\text { label B15- } \\
075.2 \mathrm{~A}\end{array}$ & $\begin{array}{l}\text { Solanum pomiferum fructu molli C.B. } \\
\text { Aurea mala, Dodo. Poma amoris Lob. } \\
\text { Cam. Apud Matth. Tab. Basileae ex horto. }\end{array}$ \\
\hline $\begin{array}{l}\text { Caspar Bauhin } \\
(1560-1624)\end{array}$ & $\underline{1577-1624}$ & $\begin{array}{l}\text { Herbarium } \\
\text { specimen + } \\
\text { label B15- } \\
075.2 \mathrm{~B} 1 \\
\end{array}$ & $\begin{array}{l}\text { Solanum pomiferum fructu rotundo striato } \\
\text { molli, C. Bauh. Lycopersicon Galeni, } \\
\text { Anguillar. Poma amoris, Dod. Gal. Lob. } \\
\text { Tab. 403. 2. Ex hortulo nostro. }\end{array}$ \\
\hline $\begin{array}{l}\text { Casper Bauhin } \\
(1560-1624)\end{array}$ & $\underline{1577-1624}$ & $\begin{array}{l}\text { Herbarium } \\
\text { specimen }+ \\
\text { label B15- } \\
075.2 \mathrm{~B} 2\end{array}$ & $\begin{array}{l}\text { Solanum pomiferum fructu rotundo striato } \\
\text { molli, C. Bauh. Lycopersicon Galeni, } \\
\text { Anguillar. Poma amoris, Dod. Gal. Lob. } \\
\text { Tab. 403. 2. Ex hortulo nostro. }\end{array}$ \\
\hline
\end{tabular}




\section{Table 2 (on next page)}

Table 2

Morphological characters of early sixteenth-century tomatoes mentioned in descriptions or visible in herbarium specimens and illustrations, arranged chronologically. 
1 Table 2: Morphological characters of early sixteenth-century tomatoes mentioned in 2 descriptions or visible in herbarium specimens and illustrations, arranged chronologically. 3

\begin{tabular}{|c|c|c|c|c|}
\hline $\begin{array}{l}\text { Author / artist } \\
\text { (year) }\end{array}$ & Collection & Flowers & Fruit shapes & Fruit colors \\
\hline $\begin{array}{l}\text { Matthioli } \\
\text { (1544) }\end{array}$ & Description & - & 'Segmented' & $\begin{array}{l}\text { 'Blood red, } \\
\text { gold' }\end{array}$ \\
\hline $\begin{array}{l}\text { Aldrovandi } \\
\text { (1551) }\end{array}$ & Specimen & Simple & No fruit & - \\
\hline $\begin{array}{l}\text { Petrollini } \\
\text { (pre-1553) }\end{array}$ & Specimen & Simple & Small immature fruit & - \\
\hline $\begin{array}{l}\text { Fuchs (1549- } \\
1556 / 1561)\end{array}$ & $\begin{array}{l}\text { Description, } \\
\text { drawing }\end{array}$ & $\begin{array}{l}\text { Simple and } \\
\text { fasciated } \\
\text { ('9 petals') }\end{array}$ & $\begin{array}{l}\text { Either spherical or } \\
\text { oblong, smooth or } \\
\text { deeply grooved }\end{array}$ & $\begin{array}{l}\text { Golden, } \\
\text { saffron, red, } \\
\text { striped, } \\
\text { whitish-yellow }\end{array}$ \\
\hline Dodoens (1553) & $\begin{array}{l}\text { Description, } \\
\text { uncolored woodcut }\end{array}$ & Fasciated & $\begin{array}{l}\begin{array}{l}\text { Ribbed, round, } \\
\text { somewhat flattened }\end{array} \\
\text { sol }\end{array}$ & $\begin{array}{l}\text { Red, yellow or } \\
\text { whitish }\end{array}$ \\
\hline Dodoens (1554) & $\begin{array}{l}\text { Description, } \\
\text { colored woodcut }\end{array}$ & Fasciated & $\begin{array}{l}\text { Ribbed, round, } \\
\text { somewhat flattened }\end{array}$ & Red \\
\hline Gesner (1553) & Color drawings & $\begin{array}{l}\text { Fasciated, } \\
\text { single? }\end{array}$ & $\begin{array}{l}\text { Round and smooth; } \\
\text { elongated and ribbed }\end{array}$ & $\begin{array}{l}\text { Red, white, } \\
\text { yellow, brown }\end{array}$ \\
\hline $\begin{array}{l}\text { Oellinger } \\
(1553)\end{array}$ & Color drawings & $\begin{array}{l}\text { Fasciated } \\
\text { and simple }\end{array}$ & \begin{tabular}{|l|} 
Ribbed and \\
segmented \\
Round and smooth
\end{tabular} & $\begin{array}{l}\text { Red, orange, } \\
\text { yellow, } \\
\text { whitish? }\end{array}$ \\
\hline Petrollini (1558) & $\begin{array}{l}\text { Specimen } \\
\text { L.2111092 }\end{array}$ & Simple & Round, smooth & Red \\
\hline $\begin{array}{l}\text { Michiel / Dalle } \\
\text { Greche (1553- } \\
1565)\end{array}$ & Color drawing & Simple & $\begin{array}{l}\text { Spherical, elongated, } \\
\text { ribbed, smooth }\end{array}$ & Red, yellow \\
\hline Rauwolf (1563) & Specimen & Simple & No fruit & - \\
\hline De Lobel (1581) & $\begin{array}{l}\text { Text, uncolored } \\
\text { woodcut }\end{array}$ & Fasciated & $\begin{array}{l}\text { Ribbed, round, } \\
\text { flattened, 'big like } \\
\text { oranges' }\end{array}$ & Red, yellow \\
\hline $\begin{array}{l}\text { Camerarius } \\
(1586,1590)\end{array}$ & $\begin{array}{l}\text { Description, } \\
\text { (un)colored } \\
\text { woodcut }\end{array}$ & $\begin{array}{l}\text { Fasciated, } \\
\text { white }\end{array}$ & $\begin{array}{l}\text { Ribbed/segmented, } \\
\text { elongated }\end{array}$ & $\begin{array}{l}\text { 'Red, golden } \\
\text { yellow, brown, } \\
\text { some very big' }\end{array}$ \\
\hline Bauhin (1598) & $\begin{array}{l}\text { Description, } \\
\text { uncolored woodcut }\end{array}$ & $\begin{array}{l}\text { Fasciated, } \\
\text { white, } \\
\text { yellow }\end{array}$ & $\begin{array}{l}\text { Ribbed, round, } \\
\text { flattened, hairy }\end{array}$ & $\begin{array}{l}\text { 'varying in } \\
\text { color' }\end{array}$ \\
\hline $\begin{array}{l}\text { Harder (1576- } \\
1600)\end{array}$ & Specimen+drawing & Simple & Round, smooth & Red \\
\hline $\begin{array}{l}\text { Libri Picturati } \\
\text { (1565-1569?) }\end{array}$ & Drawings & Fasciated & $\begin{array}{l}\text { Round, flattened, } \\
\text { ribbed }\end{array}$ & Red \\
\hline $\begin{array}{l}\text { Cesalpino } \\
(1583)\end{array}$ & Description & White & $\begin{array}{l}\text { Round, elongated } \\
\text { and ribbed/furrowed }\end{array}$ & Golden, red \\
\hline
\end{tabular}




\begin{tabular}{|l|l|l|l|l|}
\hline $\begin{array}{l}\text { Bauhin } \\
(1577-1624)\end{array}$ & $\begin{array}{l}\text { Specimen } \\
\text { B15-075.2A }\end{array}$ & Fasciated? & No fruit & - \\
\hline $\begin{array}{l}\text { Bauhin } \\
(1577-1624)\end{array}$ & $\begin{array}{l}\text { Specimen } \\
\text { B15-075.2B_1 }\end{array}$ & Fasciated & $\begin{array}{l}\text { No fruit, label } \\
\text { description: ribbed, } \\
\text { round, soft }\end{array}$ & - \\
\hline $\begin{array}{l}\text { Bauhin } \\
(1577-1624)\end{array}$ & $\begin{array}{l}\text { Specimen } \\
\text { B15-075.2B_2 }\end{array}$ & Fasciated & $\begin{array}{l}\text { No fruit, label } \\
\text { description: ribbed, } \\
\text { round, soft }\end{array}$ & - \\
\hline Bauhin (1596) & Description & - & $\begin{array}{l}\text { Ribbed, round, soft, } \\
\text { some suppressed and } \\
\text { wider }\end{array}$ & $\begin{array}{l}\text { Golden yellow } \\
\text { (most), some } \\
\text { red, pink, white } \\
\text { (rare) }\end{array}$ \\
\hline Bauhin (1598) & $\begin{array}{l}\text { Uncolored } \\
\text { woodcut }\end{array}$ & Fasciated & Ribbed, round, soft & - \\
\hline $\begin{array}{l}\text { Ducale Estense } \\
(1570-1598)\end{array}$ & Specimen & Fasciated & No fruit & - \\
\hline $\begin{array}{l}\text { Ratzenberger } \\
(1556-1592)\end{array}$ & Specimen & Fasciated? & Round & Red? \\
\hline
\end{tabular}


Table 3 (on next page)

Tomato landraces close to the En Tibi tomato (c. 1558), in order of genetic similarity 
1 Table 3: Tomato landraces close to the En Tibi tomato (c. 1558), in order of genetic 2 similarity

3

\begin{tabular}{|l|l|l|l|l|}
\hline $\begin{array}{l}\text { Identifier } \\
\text { Michel } \\
(2020)\end{array}$ & $\begin{array}{l}\text { TGRC } \\
\text { nr. (link) }\end{array}$ & $\begin{array}{l}\text { Morphological traits } \\
\text { (TGCR database) }\end{array}$ & $\begin{array}{l}\text { Geographical origin } \\
\text { (TGCR database) }\end{array}$ & $\begin{array}{l}\text { Collection } \\
\text { year }\end{array}$ \\
\hline $\begin{array}{l}\text { B-153 } \\
\text { big fruits }\end{array}$ & $\underline{\underline{\text { LA}}-}$ & Ribbed tomatoes & $\begin{array}{l}\text { Mexico: market Xol } \\
\text { Laguna, Laguna } \\
\text { Encantada, Campeche, } \\
\text { Mexico. }\end{array}$ & 1973 \\
\hline $\begin{array}{l}\text { B-249 } \\
\text { big fruits }\end{array}$ & $\underline{\text { LA-1462 }}$ & $\begin{array}{l}\text { Large fruit, kidney } \\
\text { shaped, purple }\end{array}$ & $\begin{array}{l}\text { Merida, Yucatan, } \\
\text { Mexico }\end{array}$ & 1971 \\
\hline $\begin{array}{l}\text { C-233 } \\
\text { cherry } \\
\text { tomato }\end{array}$ & $\underline{\text { LA-1218 }}$ & $\begin{array}{l}\text { Small yellow fruit (1-1.5 } \\
\text { cm). }\end{array}$ & Veracruz, Mexico & 1969 \\
\hline $\begin{array}{l}\text { C-61 } \\
\text { cherry } \\
\text { tomato }\end{array}$ & $\underline{\text { LA-2670 }}$ & $\begin{array}{l}\text { Large hairy plant, simple } \\
\text { flowers, fruits multi- } \\
\text { loculed, 2 cm. }\end{array}$ & $\begin{array}{l}\text { Family garden, 19.5 km } \\
\text { from San Juan del Oro, } \\
\text { Huayvaruni-2, Rio } \\
\text { Tambopata, Puno, Peru }\end{array}$ & 1984 \\
\hline $\begin{array}{l}\text { C-281 } \\
\text { cherry } \\
\text { tomato }\end{array}$ & $\underline{\text { LA-1286 }}$ & $\begin{array}{l}\text { Medium-sized, hairy } \\
\text { plant, flowers very tiny, } \\
\text { fruits various sizes. }\end{array}$ & $\begin{array}{l}\text { 0,5 km N of San Martin } \\
\text { de Pangoa, Junin, Peru }\end{array}$ & 1970 \\
\hline
\end{tabular}

4 


\section{Figure 1}

All extant specimens of tomatoes in sixteenth-century herbaria, in chronological order.

(A) Ulisse Aldrovandi (c. 1551), Vol 1, p. 368. The pair of leaves at the bottom of the page

belong to a Citrullus. Photo credit: University of Bologna. (B) Francesco Petrollini (pre-1553)

Photo credit: Biblioteca Angelica, Rome, c.49r, Erbario Cibo B, vol. 3. (C) Francesco Petrollini (c. 1558), L.2111092, 'En Tibi tomato'. Photo credit: Naturalis, Leiden. (D) Leonhard Rauwolf (1563), Photo credit: Naturalis, Leiden. (E) Caspar Bauhin (1577-1624) B15-075.2A. Photo credit: Herbaria Basel, University of Basel. (F) Bauhin B15-075.2B_1. Photo credit: Herbaria Basel, University of Basel. (G) Bauhin B15-075.2B_2. Photo credit: Herbaria Basel, University of Basel. (H) Hieronymous Harder (1576-1594), Photo credit: Bayerische Staatsbibliothek München, Cod.icon. 3, fol. 140v. (I) Ducale Estense herbarium (1570-1580), Photo credit: Archivio di Stato di Modena. (J) Caspar Ratzenberger (1592), Photo credit: Naturkundemuseum Kassel. Written permission to publish these images is provided in Supplementary Figure 3. 

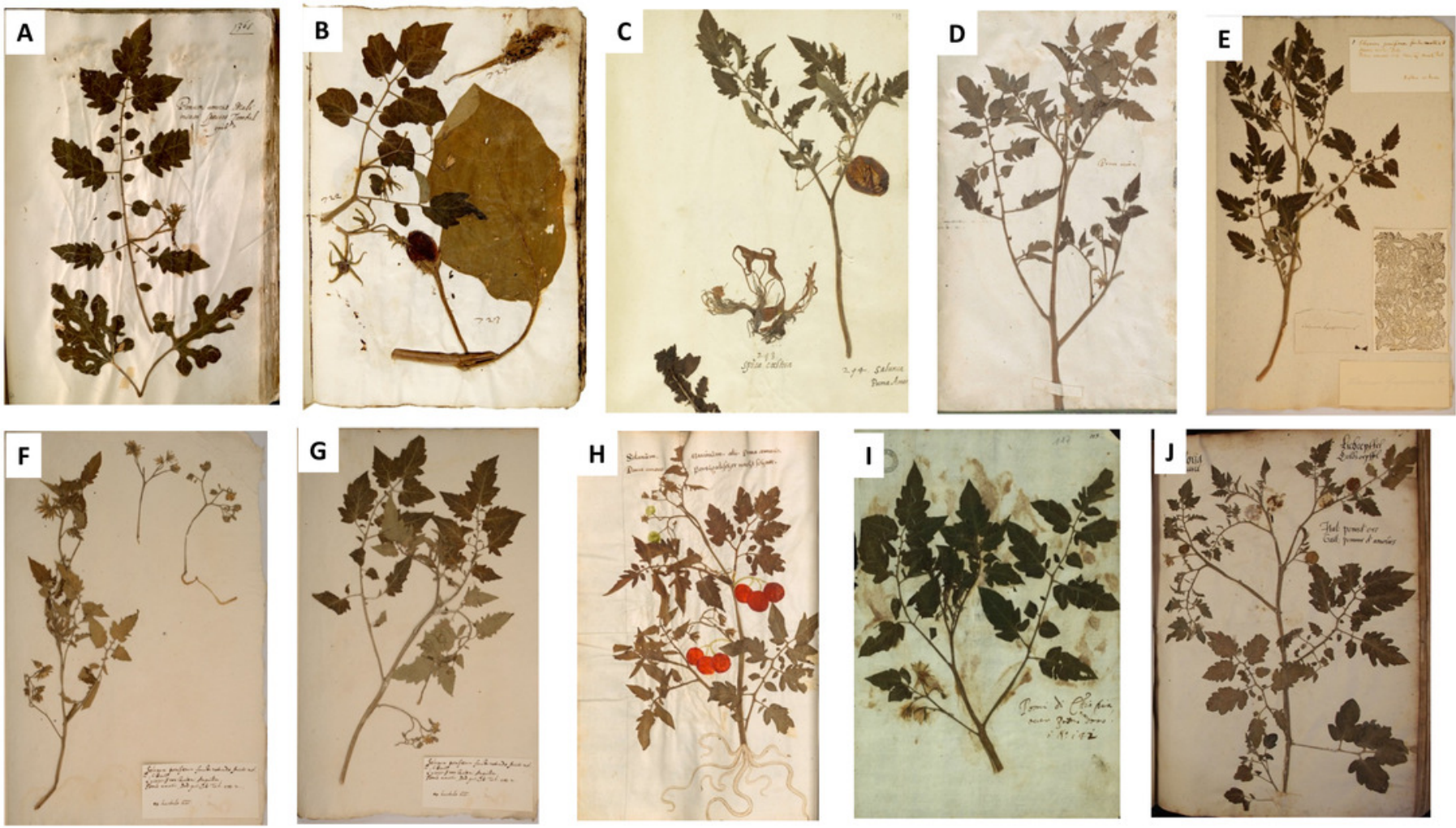


\section{Figure 2}

Published and unpublished $16^{\text {th }}$ century tomato illustrations, in chronological order.

(A) Dodoens (1553), (B) Dodoens (1554), (C) Gesner (1553), image credit:

Universitätsbibliothek der FAU Erlangen-Nürnberg, MS 2386, 37v, (D) Gesner manuscript (1553), image credit: Universitätsbibliothek der FAU Erlangen-Nürnberg, MS 2386, 42r, (E)

Fuchs (1549-1556-1561), image credit: Österreichische Nationalbibliothek, (F) Domenico Dalle Greche / Michiel (1550-1576), image credit: Biblioteca Marciana, (G) Oellinger manuscript (1553: 541), image credit: Universitätsbibliothek der FAU Erlangen-Nürnberg, MS 2362, 541, (H) Oellinger (1553: 543), image credit: Universitätsbibliothek der FAU ErlangenNürnberg, MS 2362, 543, (I) Oellinger (1553: 545), image credit: Universitätsbibliothek der FAU Erlangen-Nürnberg, MS 2362, 545, (J) Libri Picturati (1565-1569) A f(olio) 81r, image credit: Jagiellonian library, (K) Libri Picturati A 28 f(olio) 81v, image credit: Jagiellonian library, (L) De Lobel (1572), (M) Camerarius (1586: 821), (N) Camerarius (1590: 378), (0) Bauhin (1598). Written permission to publish these images is provided in Supplementary Figure 3. 

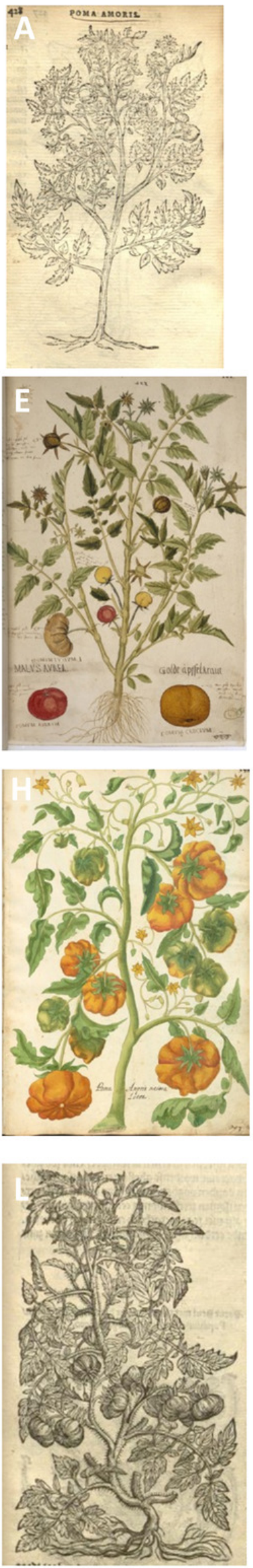
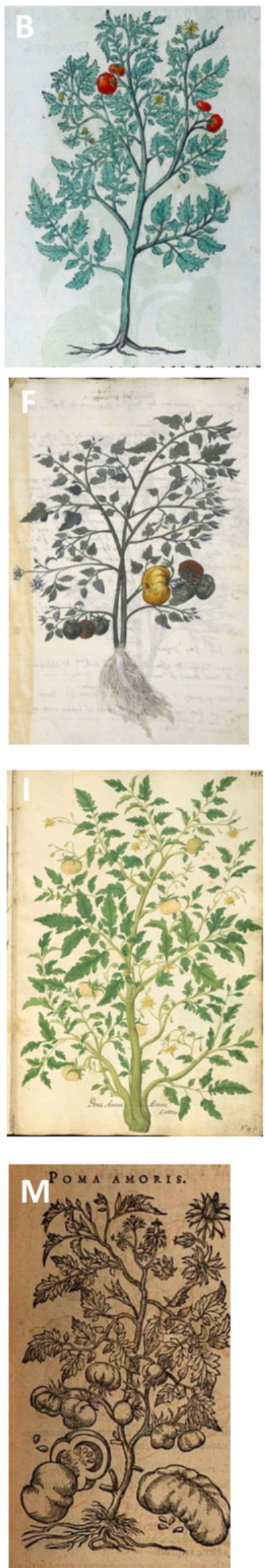
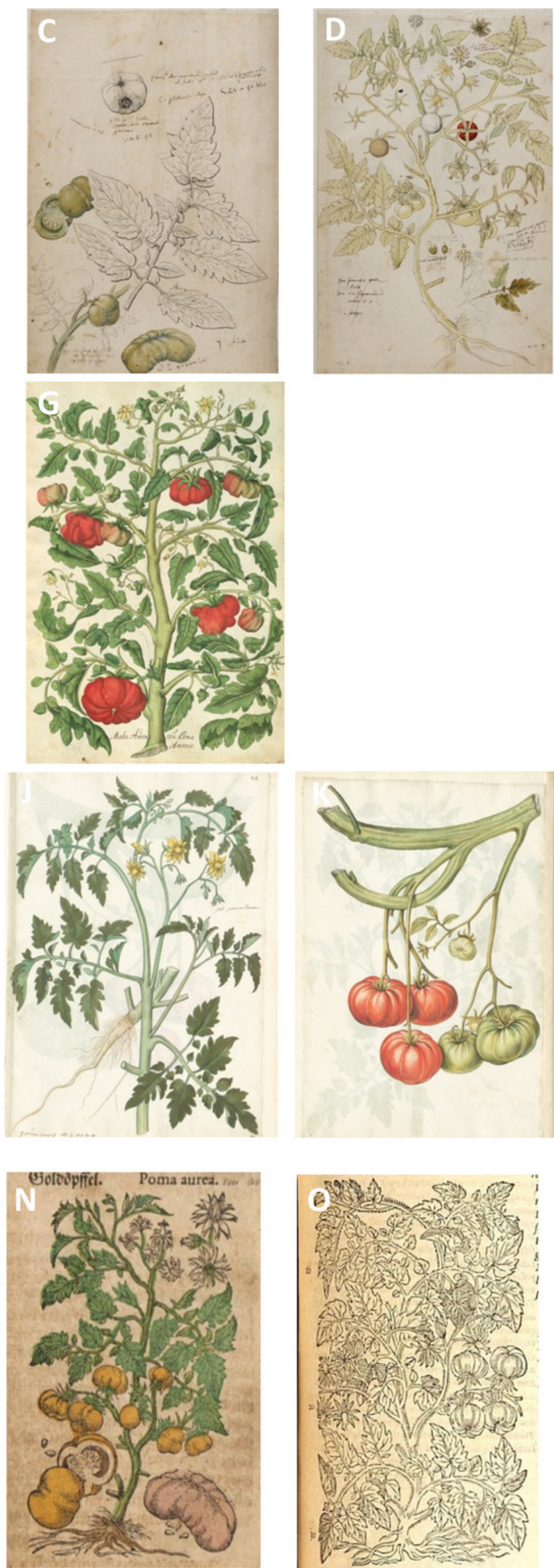


\section{Figure 3}

Results of the Neighbor Net clustering analysis, showing the genetic similarity of the wild relatives and the domesticated tomato specimens analyzed by Michel (2020).

(A) Wild individuals of S. pimpinellifolium and S. lycopersicum L. var. cerasiforme from Peru (green circles) and Ecuador (bright green circles) show a high genetic diversity (left of the figure), while a dense cluster of domesticated, genetically less diverse tomatoes is visible on the right, which includes the En Tibi specimen. (B) Enlargement of the cluster with domesticated tomatoes from Figure $3 \mathrm{~A}$, showing the nearest neighbors of the En Tibi tomato (gray circle). All distances expressed in Kimura 2-parameter substitutional distance; parsimony-uninformative SNPs excluded.
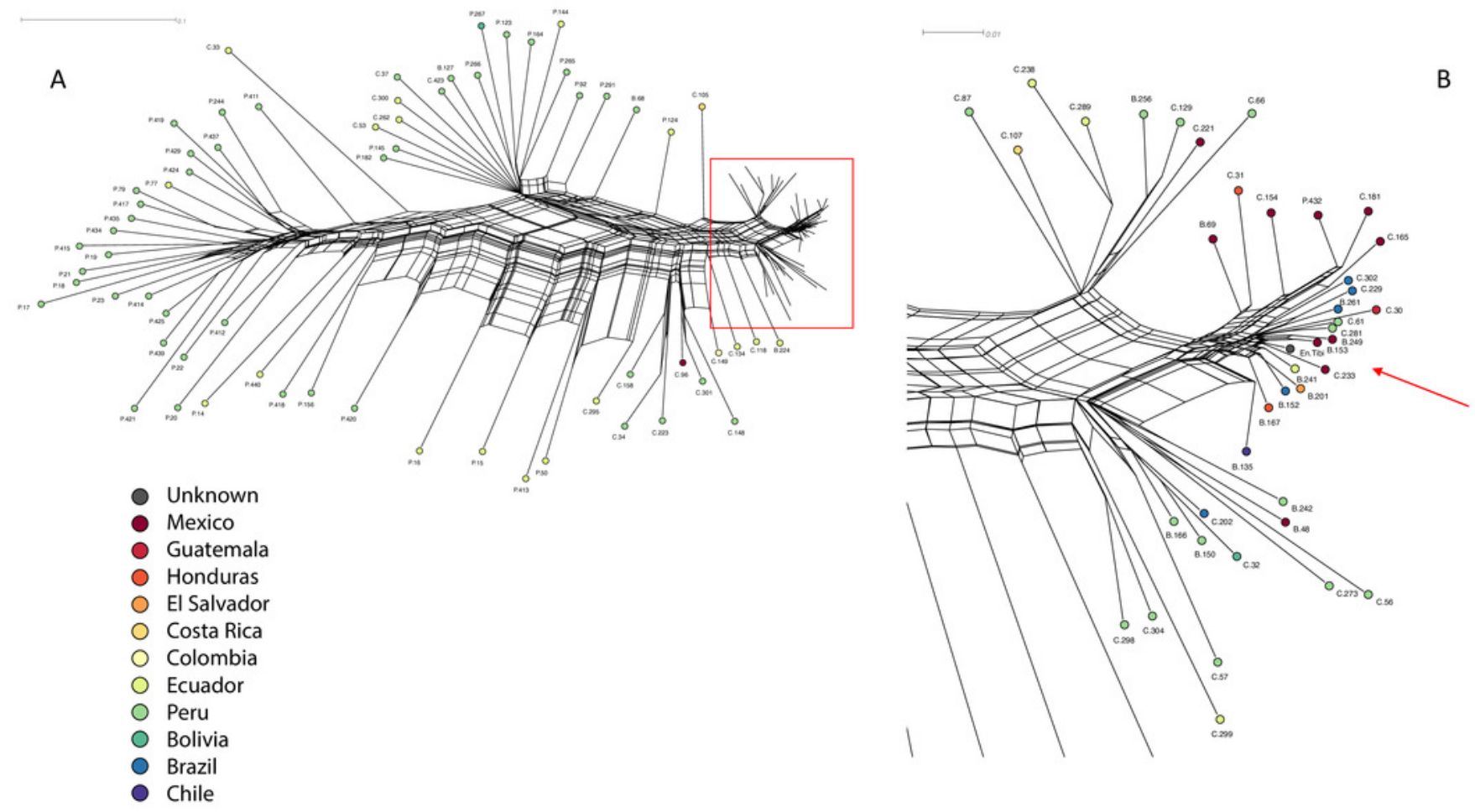